\title{
РАЗВИТИЕ МАГМАТИЧЕСКОЙ СИСТЕМЫ ПОД УДИНСКИМ ВУЛКАНИЧЕСКИМ КОМПЛЕКСОМ (КАМЧАТКА) ПО СЕЙСМИЧЕСКИМ ДАННЫМ 2017-2019
}

Гг.

Кугаенко Ю. А., Салтыков В. А., Кулаков И. Ю., Павлов В. М., Воропаев П. В., Абкадыров И. Ф., Комзелева В. П.

\begin{abstract}
Аннотация
В статье рассматривается развитие пробуждающейся магматической системы под Удинским вулканическим комплексом, расположенным в юго-восточной части Ключевской группы вулканов на Камчатке и прекратившим активность несколько тыс. лет назад. Информационной основой исследования являются записи региональных и временных сейсмических станций и камчатский каталог землетрясений. С октября 2017 г. под Удинскими вулканами на глубине преимущественно до 20 км развивается сейсмическая активизация, что может свидетельствовать о начале следующего эпизода их активности. Землетрясения относятся к длиннопериодным (LP) сейсмическим событиям (преобладающий частотный диапазон 0.5-5 Гц), которые в мировой практике связываются с продвижением вязкой магмы и резонансными явлениями в магмопроводящем канале. Поэтому мы рассматриваем их как признак поступления новых порций вещества в питающую систему вулкана.
\end{abstract}

Результаты работы временной сети сейсмических станций, установленных в окрестности Удинского комплекса (май-июль 2018 г.), позволили уточнить расположение гипоцентров и показали, что большинство землетрясений сконцентрировано под вулканом Большая Удина на глубине 5-15 км. Пассивная сейсмическая томография(алгоритм LOTOS) позволила обнаружить непосредственно под вулканом Большая Удина на глубинах менее 5 км аномалию с повышенными скоростями Р волн, пониженными скоростями S волн и повышенным значением отношения VP/VS. Такая комбинация сейсмических параметров может быть связана с внедрением частично расплавленной магмы и/или жидких флюидов. Сопоставление с результатами томографических работ 2014-2015 гг. показывает, что к 2018 г. аномалия сместилась в область меньших глубин.

Сейсмические данные в комплексе с имеющейся геолого-геофизической информацией показывают, что Удинская магматическая питающая система проявляет признаки движения вязкой магмы на глубинах средней коры, что является косвенным подтверждение возобновления связи между промежуточным очагом и мантийным источником после длительного периода покоя.

Ключевые слова: сейсмическая активизация, сейсмичность, вулкан, система магматического питания, Большая Удина, Малая Удина, сейсмическая томография, длиннопериодные землетрясения

\section{Ключевые слова:}

Сейсмическая активизация, сейсмичность, вулкан, система магматического питания, Большая Удина, Малая Удина, сейсмическая томография, длиннопериодные землетрясения 


\title{
РАЗВИТИЕ МАГМАТИЧЕСКОЙ СИСТЕМЫ ПОД УДИНСКИМ ВУЛКАНИЧЕСКИМ КОМПЛЕКСОМ (КАМЧАТКА) ПО СЕЙСМИЧЕСКИМ ДАННЫМ 2017-2019 гг.
}

\author{
Ю.А. Кугаенко ${ }^{1}$, В.А. Салтыков ${ }^{1}$, И.Ю. Кулаков ${ }^{2,3}$, В.М. Павлов ${ }^{1}$, \\ П.В. Воропаев ${ }^{1}$, И.Ф. Абкадыров ${ }^{1,4}$, В.П. Комзелева ${ }^{2}$ \\ ${ }^{1}$ Федеральный исследовательский центр «Единая \\ геофизическая служба Российской академии наук», Камчатский филиал, \\ 683006, Петропавловск-Камчатский, бульвар Б.И. Пийпа, 9, Россия \\ ${ }^{2}$ Институт нефтегазовой геологии и геофизики им. А.А. Трофимука СО РАН, \\ 630090, Новосибирск, просп. Академика Коптюга, 3, Россия \\ ${ }^{3}$ Новосибирский государственный университет, \\ 630090, Новосибирск, ул. Пирогова, 2, Россия \\ ${ }^{4}$ Институт вулканологии и сейсмологии ДВО РАН, \\ 683006, Петропавловск-Камчатский, бульвар Б.И. Пийпа, 9, Россия
}

\section{ВВЕДЕНИЕ}

Исследование магматических питающих систем вулканов является одной их основных фундаментальных задач в области наук о Земле. Пробуждение и последующая динамика магматического аппарата под вулканом может отражаться в сейсмичности. В отсутствие других видов наблюдений сейсмические данные являются главным источником информации о потенциальной активизации вулкана, относящегося по существующей классификации к потухшим [Мелекесцев и др., 2001; Новейший..., 2005]. Именно такая уникальная ситуация (сейсмическая активизация под Удинским вулканическим комплексом (УВК)) наблюдается с октября 2017 г. на Камчатке по данным камчатской региональной сети сейсмических станций [Салтыков и др., 2018].

В мировой практике сейсмическая активизация рассматривается как seismic unrest отклонение от обычного, фонового, поведения вулкана [Diefenbach et al., 2009; Phillipson et al., 2013; Volcanic Unrest..., 2019]. По данным исследования [Phillipson et al., 2013] 64\% различных зафиксированных на вулканах аномалий, рассматриваемых как volcanic unrest, заканчиваются извержениями. Извержение нельзя исключить и в нашем случае, так как длительная Удинская сейсмическая активизация свидетельствует о нарушении стационарного состояния среды, что может быть связано с внедрением магмы под Удинские вулканы.

Такая необычная ситуация, развивающаяся в реальном времени, дает редкую возможность исследовать пробуждение магматической системы недействующего вулкана. Ситуация является уникальной не только в российской, но и в мировой практике сейсмологических наблюдений в районах вулканической активности. 


\section{УДИНСКИЙ ВУЛКАНИЧЕСКИЙ КОМПЛЕКС}

В юго-восточной части Ключеской группы вулканов (КГВ) находятся два крупных недействующих стратовулкана: Большая Удина и Малая Удина, которые вместе с несколькими экструзивными куполами составляют единую группу - Удинский вулканический комплекс (УВК).

Ключевская группа вулканов является одним из активнейших и наиболее изученных вулканических кластеров в мире. Она включает как действующие (Ключевской, Безымянный, Ушковский, поле ареального вулканизма Толбачинский Дол, Плоский Толбачик), так и потухшие (Удины, Зимины, Крестовский, Средний) вулканы (рис. 1). Однако даже в пределах единой КГВ вулканы исследованы далеко неравномерно. УВК, находящийся на периферии КГВ, можно рассматривать как ее наименее освоенный сектор.

Геологические и петрографические исследования показали, что все многообразие вулканических пород КГВ может быть разделено на две формации (совокупности горных пород со сходными условиями образования): базальт-андезибазальтовую (I) и базальтандезидацитовую (II) [Ермаков, 1977; Мелекесцев и др., 1991]. Согласно сейсмологическим данным и ГСЗ [Балеста, 1981] источники магмы КГВ для пород формации I располагаются в верхней мантии и поступали к поверхности по системе разломов. Источники пород формации II предположительно залегают в коре и могут быть связаны с коровыми разломами в юго-восточной части КГВ, которые трассируются экструзиями и вулканами среднекислого состава. K формации I относятся продукты вулканов Ключевской, Камень, Острый и Плоский Толбачик, Толбачинский Дол, Крестовский, Ушковский. Формация II объединяет породы вулкана Безымянного, Удинских и Зиминских вулканов и экструзий. Более современные представления о генезисе среднекислых вулканитов представлены, например, в монографии [Толбачинское..., 2017].

Наиболее полно Удинские вулканы описаны в монографиях [Тимербаева, 1967; Ермаков, 1977]. Эти вулканы расположены на едином тектоническом нарушении С3 простирания, в зоне сочленения трех крупных тектонических структур, испытавших в верхнечетвертичное время вертикальные подвижки различных знаков и амплитуд. Вулканы Большая и Малая Удина сформировались в основном в верхнем плейстоцене. Состав пород - преимущественно андезиты ( $~ 80 \%)$ и базальты ( $20 \%)$.

Большая Удина - стратовулкан двухъярусного строения. Нижний комплекс мощностью не менее 400 м сложен андезитами и дацитами. Пирокластика преобладает над лавами. Формирование нижнего яруса постройки завершилось выбросом пемз и сильнопористых пемзовых андезито-дацитов. К.М. Тимербаева [1967] отмечает, что 
эксплозивная деятельность этого периода имеет характер косых направленных взрывов и близка к типу извержений вулкана Безымянный, после чего в эруптивной деятельности Большой Удины наступил перерыв. В верхнем комплексе выделено три толщи: андезибазальтовая, гиперстеновых андезитов и двупироксеновых андезитов. Формирование указанных толщ чередовалось с периодами покоя вулкана. Вулкан венчает сильно разрушенная вершинная экструзия и небольшой ледник.

Малая Удина сформировалась за относительно короткое время, 2 тыс. лет, в результате эксплозивно-эффузивной деятельности (коэффициент эксплозивности не менее 75 \%), которая развивалась на фоне перерыва в активности Большой Удины между формированием нижнего и верхнего яруса ее постройки. Стратовулкан Малая Удина сложен базальтами и андезибазальтами. Конус вулкана рассечен многочисленными дайками базальта и одной дайкой рогообманкового андезита. Заложение Малой Удины предположительно связано с прорывом нового канала в плоскости тектонического нарушения, единого для Удинских вулканов. Причиной прорыва могла быть закупорка жерла Большой Удины относительно вязкой кислой лавой. Возобновление извержений Большой Удины явилось возможной причиной ослабления, а затем и полного прекращения деятельности Малой Удины. В целом, по мнению К.М. Тимербаевой [1967], образование Малой Удины является лишь незначительным эпизодом на фоне деятельности Большой Удины, длительность истории формирования которой оценивается в 15-17 тыс. лет. Однако в основании Малой Удины В.А. Ермаков [1977] выделяет пологий щитообразный правулкан и связанные с его деятельностью позднеплейстоценовые экструзии, что добавляет еще один вулкан к УВК, продлевает и усложняет всю историю развития этого вулканического комплекса.

Завершающим этапом деятельности Удинских стратовулканов является выжимание экструзивных куполов после очередного обоюдного периода покоя. Экструзии сформированы рогообманковыми андезитами. В монографиях их возраст оценивается верхним-средним голоценом (то есть в первые единицы тыс. лет). Этот вывод вызывает сомнения у вулканологов. В итоге в перечень активных, то есть извергавшихся в ходе последних 3.5 тыс. лет, вулканов России Удинские вулканы не включены [Мелекесцев и др., 2001; Новейший..., 2005], хотя альтернативные датировки возраста молодых удинских экструзий все еще отсутствуют.

Состав пород Удинских вулканов предполагает заключительное формирование магмы в коровой обстановке, то есть представляется вероятным существование малоглубинного промежуточного магматического очага наряду с мантийным магматическим источником [Тимербаева, 1967]. В [Ермаков, 1977] глубина 
промежуточного очага оценена в 20 км. Он не являлся полностью изолированным резервуаром, так как связь промежуточного очага с более глубоким мантийным бассейном косвенно подтверждается синхронным (одократным) излиянием на обоих Удинских вулканах основных лав [Тимербаева, 1967].

Новое опробование пород УВК, выполненное в 2014-2015 гг. [Churikova et al., 2017], подтверждает их сходство с продуктами вулкана Безымянного. Напомним, что вулкан Безымянный еще в середине XX века считался потухшим, а его выход из состояния покоя ознаменовался в 1956 г. катастрофическим извержением направленного взрыва [Горшков, Богоявленская, 1965; Богоявленская, и др., 1991; Girina, 2013]. Этот вулкан сохраняет эруптивную активность и в настоящее время: для него характерны многокилометровые газо-пепловые выбросы и сход пирокластических потоков ${ }^{1}$. Поэтому наблюдаемая сейсмическая активизация под УВК вызывает озабоченность, так как сходство составов пород означенных вулканов предполагает возможность сходных сценариев их эруптивной деятельности.

\section{ИСТОЧНИКИ СЕЙСМОЛОГИЧЕСКИХ ДАННЫХ}

Информационной основой для исследований сейсмичности КГВ являются сейсмические записи и каталог ${ }^{2}$ региональной сети сейсмических станций Камчатского филиала Федерального исследовательского центра «Единая геофизическая служба Российской Академии наук» (КФ ФИЦ ЕГС РАН). В районе КГВ сеть сейсмических станций ориентирована на мониторинг основных действовавших в XX-XXI веке опасных вулканов: Ключевского и Безымянного [Чебров и др., 2012, 2013]. Даже вулкан Плоский Толбачик и поле ареального вулканизма Толбачинский Дол, где произошли известные феерические извержения 1975-1976 гг. и 2012-2013 гг. [Большое..., 1984; Толбачинское..., 2017], оказались на периферии этой группы станций. Удинские вулканы, не проявлявшие признаков активности, тем более не учитывались при разработке конфигурации системы мониторинга КГВ.

В настоящее время в районе КГВ работают 13 сейсмостанций (рис. 1б). Они расположены в секторе с углом в $\sim 120^{\circ}$ по отношению к УВК, ближайшие станции находятся на расстоянии 20-25 км к северу и западу от Удинских вулканов. Таким образом, система мониторинга в имеющейся конфигурации является односторонней, неоптимальной для локации землетрясений в южной части КГВ.

Проблемы определения гипоцентров землетрясений этого района обсуждались нами в [Кугаенко и др., 2017б] по результатам работы временной сейсмометрической сети.

1 Фактографическая база данных КФ ФИЦ ЕГС РАН «Активность вулканов Камчатки» http://www.emsd.ru/ ssl/monitoring/main.htm

2 Единая информационная система сейсмологических данных КФ ФИЦ ЕГС РАН http://sdis.emsd.ru/main.php 
Было показано, что при привлечении данных дополнительных станций гипоцентры смещаются на расстояния, превышающие заявленные в каталоге ошибки их определения. По нашему мнению, проблема остается нерешенной. В контексте изучения Удинской активизации первостепенное значение имеет достоверность определения глубины сейсмических событий.

Для повышения достоверности гипоцентрии и получения новых знаний об Удинских вулканах в мае-июле 2018 г. сотрудниками Института нефтегазовой геологии и геофизики им. Трофимука РАН и Института вулканологии и сейсмологии ДВО РАН были организованы временные наблюдения дополнительными сейсмическими станциями. Группа имела апертуру $\sim 10$ км и включала четыре широкополосных велосиметра GURALP CMG-6TD.

\section{РЕЗУЛЬТАТЫ МОНИТОРИНГА СЕЙСМОГЕНЕРИРУЮЩЕГО ОБЪЕМА ПОД УВК}

Удинская сейсмическая активизация. В настоящее время, с октября 2017 г., под Удинской вулканической группой выявлена аномалия сейсмического режима, не имеющая аналогов в практике сейсмологических наблюдений за этими вулканами, которая представляет собой статистически значимую сейсмическую активизацию низкого энергетического уровня. С октября 2017 г. по март 2019 г. зарегистрировано 2.5 тыс. землетрясений с $2.5 \leq K_{\mathrm{s}}^{3} \leq 10.1$, $\left(1 \leq \mathrm{ML}^{4} \leq 4.3\right)$ на глубине преимущественно до 20 км. Согласно камчатскому каталогу, ошибки определения положения землетрясений Удинской активизации и по эпицентру, и по глубине составляют $3 \pm 2$ км (погрешность соответствует среднеквадратичному отклонению). Дополнительно в работе [Дрознин и др., 2019] показано, что для гипоцентров Удинских землетрясений линейные размеры доверительной области могут достигать 15-25 км с возможным формированием альтернативных решений на разных глубинах (причины кроются в неоптимальном расположении сейсмических станций и неточности скоростного разреза). Таким образом, камчатский каталог дает лишь общее представление о положении и конфигурации Удинской активизации. Необходимо отметить (это видно из рис. 3), что область, захваченная сейсмической активизацией, значительно превышает размеры возможного магматического очага под Удинскими вулканами, который можно условно очертить по расположению эруптивных центров УВК (стратовулканов и экструзий, точечный пунктир на рис. 1в). Как видим, разброс Удинских эруптивных центров не превышает 10 км, в то время как размеры сейсмической активизации в плане составляют более $20 \times 20$ км.

$3 \mathrm{~K}_{\mathrm{s}}=\lg \mathrm{E}($ Дж) - энергетический класс по классификации С.А. Федотова [Федотов, 1972]

$4 \mathrm{ML}$ - локальная магнитуда, связываемая с $\mathrm{K}_{\mathrm{S}}$ соотношением ML = 0.5K -0.75 [Чубарова и др., 2010] 
В ходе детальных сейсмологических наблюдений на Камчатке (с 1961 г.) в данной области фиксировалась слабая сейсмическая активность. С 1961 по 1998 г. под Удинскими вулканами по данным камчатского каталога было зафиксировано всего два землетрясения 29.04.1976 г. $K_{S}=8.5(\mathrm{ML}=3.5)$ и 02.07.1994 г. $K_{S}=6.7(\mathrm{ML}=2.6)$, а с 1999 г. по сентябрь 2017 - 100 более слабых событий.

Для того чтобы проиллюстрировать, насколько ярко и уверенно проявляется Удинская сейсмическая активизация в 2017-2019 гг., на рис. 3 представлена сейсмичность КГВ с 2015 г. по первый квартал 2019 г. Видны кластеры землетрясений, связанные с активизациями вулканов КГВ: Ключевского (К на рис. 3), Безымянного (Б), Плоского Толбачика (Т). На рис. Зв выделяется вспышка сейсмичности в районе зоны ледопада ледника Бильченок на вулкане Ушковском (Л). На юго-восточном фланге КГВ стабильно проявляется рассеянная сейсмичность Толудской эпицентральной зоны (ТЭ3) [Кугаенко и др., 2017а]. Удинская активизация начинается в октябре 2017 г. (У на рис. Зе). Пространственно этот сейсмогенный объем на юге соприкасается с ТЭЗ, на северо-западе - с облаком землетрясений вулкана Плоский Толбачик (Т). Удинская сейсмическая активизация представляет собой роевую последовательность землетрясений с магнитудой до $\mathrm{ML}=4.3$. По данным камчатского каталога землетрясений сейсмогенерирующий объем оценочно захватывает $\sim 8000$ км³ в диапазоне глубин преимущественно до 20 км.

В 2017-2019 гг. сейсмический процесс развивался нелинейно, с усилением (рис. 4). Скорости сейсмического потока и выделившейся сейсмической энергии превышали среднемноголетние значения в январе 2018 г. в 35 и 25 раз соответственно, а в августе 2018 г. - в 70 и 1600 раз. В августе 2018 г. было зафиксировано три землетрясения с магнитудой $\mathrm{ML}=3.7$, 3.3, 3.2, превысившей значения, наблюдавшиеся с начала активизации. Сильнейшее по энергии землетрясение с $\mathrm{ML}=4.3$ произошло 06.02.2019 г. на глубине $19 \pm 4$ км. Таким образом, отмечен рост максимальной магнитуды сейсмических событий.

Для мониторинга вариаций уровня сейсмичности Удинской активизации используется шкала СОУС’09, в которой в качестве параметра, характеризующего уровень сейсмичности заданного пространственного объекта в определенный временной интервал, используется статистическая функция распределения сейсмической энергии [Салтыков, 2011]. Уровень сейсмичности в течение 1.5 лет (октябрь 2017 г. - март 2019 г.) находится на высоком - экстремально высоком уровне (рис. 5). Наблюдается пульсирующий характер уровня сейсмичности. Это особенно заметно в малых временных окнах, где пульсации имеют квазипериодический характер. Всплески сейсмичности, вероятно, соответствуют эпизодам развития магматического очага, что отражается в динамике сейсмического потока. 
С середины 2018 г. наблюдается миграция сейсмичности в южном направлении (рис. 6а), однако максимальные значения параметров сейсмического режима тяготеют к постройке Большой Удины (рис. 6б, 6в).

Механизм очага землетрясения 06.02.2019 г. ML=4.3. Рассмотрим механизм очага сильнейшего на настоящий момент землетрясения Удинской сейсмической активизации, которое произошло 06.02.2019 г. и имело магнитуду $\mathrm{ML}=4.3$. Параметры очага этого землетрясения были определены в КФ ФИЦ ЕГС РАН 5 по записям камчатских сейсмических станций двумя способами: по знакам первых вступлений Р-волн и по широкополосным цифровым сейсмограммам путем расчета тензора сейсмического момента (ТСМ) (табл.).

В первом случае механизм очага определен по знакам первых вступлений объемных волн [Введенская, 1969] на региональных сейсмических станциях по программе A.B. Ландера FA2011 [Ландер, 2013].

Процедура оценки механизма по волновым формам описана в работах [Павлов, Абубакиров, 2012; 2017]. Компоненты ТСМ определяются посредством минимизации нормированной функции невязки є между наблюденными и синтетическими волновыми формами смещений. При расчетах предполагалось, что ТСМ принадлежит к типу «двойной диполь без момента». Широкополосные сейсмические записи, которые использовались в данной работе, представлены на рис.7а.

Отметим, что первый метод, опирающийся на знаки вступлений, несет информацию только о начальной стадии разрыва в очаге, в то время как механизм, определенный по длиннопериодным волновым формам, относится к очагу в целом. Поэтому в общем случае эти два механизма могут не совпадать.

Результаты расчета механизма землетрясения 6.02.2019г. через ТСМ приведены на рис.7а. Оптимальная глубина очага соответствует 15 км. Временная функция источника дельта-функция («мгновенный импульс»). Значение сейсмического момента составляет $\mathrm{M} 0=2.0 \cdot 10^{15} \mathrm{H} \cdot$ м. Моментная магнитуда $M_{w}=2 / 3 \cdot\left(\lg \left(\mathrm{M}_{0}[\mathrm{H} \cdot \mathrm{M}]\right)-9.1\right)=4.1$. Значение минимальной невязки $\varepsilon=19 \%$ свидетельствует о хорошем согласии наблюденных и расчетных волновых форм (рис. 7б).

На основе значения моментной магнитуды $M_{w}$ могут быть получены оценки протяженности очага землетрясения 6.02.2019 г. В работе [Гусев, Мельникова, 1990]. площадь разрыва связана с $M_{w}$ корреляционной зависимостью $\lg \left(S\left[\mathrm{kM}^{2}\right]\right)=M_{w}-4.1$. Если площадка разрыва - круг радиуса $R$, то $R=(S / \pi)^{1 / 2}$. В нашем случае $M_{w}=4.1$ и $R=0.56$ км. 
Таким образом, в предположении круговой площадки разрыва размер очага можно оценить как $D=2 R \approx 1.1$ км.

Механизм очага, определенный по знакам Р-волн, по обеим нодальным плоскостям представляет собой сбросо-сдвиг: угол подвижки $-133^{\circ}$ по плоскости NP1 и -38 по NP2. При расчете механизма по широкополосным сейсмограммам по обеим плоскостям, падающим субвертикально, зафиксирован практически чистый сдвиг с небольшой сбросовой компонентой: угол подвижки $-174^{\circ}$ по плоскости NP1 и $-16^{\circ}$ по NP2. Механизмы не совпадают, но дополняют друг друга, иллюстрируя сложный характер подвижки в очаге землетрясения: сбросо-сдвиг в начальной фазе разрыва, в дальнейшем переходящий в сдвиг при сохранении сбросовой компоненты. В то же время оси растяжения Т в обоих вариантах расчета близки: субгоризонтальны и имеют субширотное направление (табл.). Отметим, что сильнейшее землетрясение этого сегмента КГВ Толудское землетрясение 30.11.2012 г. с $\mathrm{ML}=4.9, \mathrm{M}_{\mathrm{W}}=4.8$ и его афтершок с $\mathrm{ML}=4.3, \mathrm{M}_{\mathrm{W}}=4.2$ имели сходный механизм очага (сброс со сдвиговой компонентой) и субгоризонтальную ось напряжения растяжения, ориентированную субширотно, вкрест основному магмопроводящему разлому [Кугаенко и др., 2017а].

В соответствии с особенностями тектоники южной части КГВ (основное тектоническое нарушение - глубинный разлом север-северо-восточного простирания, рис.1) при выборе плоскости разрыва нами отдается предпочтение нодальной плоскости северо-восточного простирания NP2.

Длиннопериодные (LP) землетрясения. Анализ записей землетрясений Удинской активизации показал, что они относятся к длиннопериодным (LP) землетрясениям, характерным для вулканических районов (преобладающий частотный диапазон 0.5-5 Гц, длинная кода, четкое первое вступление), рис. 8а. В мировой практике LP землетрясения связываются с продвижением вязкой магмы под действием новых порций поступающего вещества и резонансными явлениями в магмопроводящем канале и рассматриваются как один из признаков оживления магматической системы (magmatic unrest) и, соответственно, как потенциальный предвестник извержения [Chouet, 1996; Chouet et ад., 1994; Sgattoni et al., 2016; Frank et al., 2018; Токарев, 1981; и др. ]. Параметры LP записей связаны с газонасыщенностью и другими характеристиками магмы [Kumagai, Chouet, 1999].

LP землетрясения непосредственно несут информацию о расположении элементов магматической питающей системы под УВК. Среди событий Удинской активизации выделяются кластеры со схожими волновыми формами (рис. 8б, 8в). Возможно объединение сейсмических событий в «семейства» по корреляции волновых форм. В вулканических районах каждое «семейство» LP событий может быть связано со своим 
единым магмопроводящим каналом [Chouet, 1988; Espindola et al., 2005; Shapiro et al., 2017; и др.]. Увеличение числа «семейств» интерпретируется как возможное разветвление магматической системы и появление новых путей (каналов) миграции магмы. Сам факт наличия таких кластеров («семейств») намечает одно из возможных направлений мониторинга УВК - поиск и картирование LP землетрясений. Это - направление будущих исследований.

Результаты работы временной сети. В мировой практике исследования пробуждающихся вулканов начинаются с оперативной организации дополнительный наблюдений, в первую очередь - сейсмологических. Как было упомянуто выше, в маеиюле 2018 г. в районе УВК были проведены временные наблюдения дополнительными сейсмическими станциями. Расстановка временных станций была ориентирована на всесторонний охват Удинских вулканов, чтобы получить записи локальных землетрясений на более низком энергетическом уровне, чем это позволяет региональная сеть. Следует отметить, что для вулканических районов характерны значительные коровые неоднородности, как это было показано для КГВ томографическими реконструкциями (например, [Koulakov et al., 2013]). Поэтому использование локальной малоапертурной группы станций для исследования землетрясений, происходящих в пределах группы, позволяет уменьшить влияние латеральных коровых неоднородностей на результаты расчета гипоцентров и получить более достоверные результаты.

В записях четырех станций временной сети за два месяца работы были идентифицированы более 500 локальных землетрясений, большая часть которых не обнаруживалась посредством региональной сети (далее - набор данных N1). Вычисление координат этих землетрясений проведено одновременно с определением трехмерного распределения скоростей $\mathrm{P}$ и $\mathrm{S}$ волн в верхней коре в районе реализации землетрясений с использованием алгоритма пассивной сейсмической томографии LOTOS [Koulakov, 2009]. Распределения скоростей Р и S волн, отношения Vp/Vs, а также положения гипоцентров, рассчитанных в трехмерной сейсмической модели, показаны в одном горизонтальном и двух вертикальных сечениях на рис. 9.Детальное описание этой модели приведено в статье [Koulakov et al., 2019]. Согласно этим данным, большая часть зарегистрированных землетрясений расположена непосредственно под вулканом Большая Удина или немного южнее на глубинах от 5 до 15 км. Было обнаружено, что непосредственно под вулканом Большая Удина наблюдается аномалия с повышенными скоростями $\mathrm{P}$ волн и пониженными скоростями S волн, чему соответствует повышенное значение отношения $\mathrm{V}_{\mathrm{p}} / \mathrm{V}_{\mathrm{s}}$. При этом, максимальная интенсивность этих аномалий прослеживается на глубинах менее 5 км. Такая комбинация сейсмических параметров часто наблюдается под 
активными вулканами и связывается с внедрением частично расплавленной магмы и/или жидких флюидов. В рамках этого исследования была проведена серия синтетических тестов, нацеленных на оценку границ применимости метода сейсмической томографии и степени достоверности локализации землетрясений для сети с четырьмя станциями. Один из таких тестов приведен в нижнем ряду на рис. 9. В этом случае синтетическая модель задавалась в виде двух аномалий, расположенных одна под другой на вертикальном сечении. Граница смены знака в этом случае располагалась на глубине 4 км. Значения аномалий скоростей $\mathrm{P}$ и $\mathrm{S}$ волн имели разные знаки, что обеспечивало контрастные вариации отношения $\mathrm{V}_{\mathrm{p}} / \mathrm{V}_{\mathrm{s}}$. Результат восстановления этой модели показывает надежное определение глубины границы смены знака, что свидетельствует о достаточно высоком вертикальном разрешении. Синтетические тесты позволили оценить погрешность определения гипоцентров с помощью локальной сети, которая, в среднем, не превышает 1.5 км. Таким образом, использование данных временной сети для реализации томографической инверсии и локализации сейсмичности позволило существенно сократить ошибку определения гипоцентров и выявить сейсмические атрибуты, указывающие на возможное насыщение пород под вулканом жидкой фазой (расплавами и/или флюидами).

Кроме того, данные локальной сети были проанализированы совместно с данными региональной сети. Был выбран контрольный набор землетрясений, которые, согласно камчатскому каталогу, произошли внутри полигона временной сети и при этом были зарегистрированы всеми четырьмя временными станциями. Таких землетрясений набралось немногим больше 60 (далее - набор данных N2). Расчеты проведены по стандартной методике, применяемой в КФ ФИЦ ЕГС РАН для рутинной обработки землетрясений: использована программа DIMAS [Дрознин, Дрознина, 2010] и локальная одномерная скоростная модель. Кроме записей временной сети к расчетам гипоцентров этих землетрясений были подключены данные двух ближайших к УВК региональных станций, то есть каждое землетрясение обрабатывалось по данным шести сейсмостанций.

Результаты представлены на рис. 10. Несмотря на то, что использованы независимые методы расчетов и значительно отличающиеся между собой наборы входных данных, результаты гипоцентрии хорошо согласуются между собой:

- облако эпицентров стало более компактным по сравнению с данными камчатского каталога КФ ФИЦ ЕГС РАН и сконцентрировалось в районе вулкана Большая Удина;

- среда под вулканом Малая Удина асейсмична (в период работы временной сети);

- облако эпицентров вытянуто в субмеридиональном (север-северо-восточном) направлении; 
- распределение землетрясений по глубине одномодальное, максимальное число сейсмических событий локализовано в диапазоне глубин 9-15 км.

Особенности распределения землетрясений набора N1 в четырех диапазонах глубин представлены на рис. 10г. Видно, что облако землетрясений имеет различную конфигурацию в различных горизонтальных сечениях. На глубинах до 5 км это узкий кластер северо-восточного простирания, почти целиком попадающий под постройку вулкана Большая Удина. С увеличением глубины облако расплывается, выходит из-под конуса стратовулкана и распространяется в северную часть ТЭЗ. При этом его простирание меняется на север-северо-восточное, что соответствует простиранию разлома, пересекающего Большую Удину в этом направлении. В диапазонах глубин до 15 км четко прослеживается повышенная группируемость землетрясений именно под вулканом Большая Удина. Глубже землетрясения единичны и не имеют четкой привязки к вулканам. Возможно, различия в конфигурации облака эпицентров на разных глубинах связаны с различным направлением разноглубинных трещинных кластеров, сосредоточенных по УВК.

Набор N2 малочисленен (рис. 10в), поэтому для него не удается выделить такие детали глубинного распределения гипоцентров. Однако в целом облако землетрясений этого отрезка времени делится на две части: первая располагается под конусом Большой Удины, вторая - под южным подножием вулкана, что в целом согласуется с распределением землетрясений набора N1.

\section{ОБСУЖДЕНИЕ РЕЗУЛЬТАТОВ}

Сейсмическая активизация несет новую информацию об УВК. Сейсмические данные в комплексе с имеющейся геолого-геофизической информацией позволяют сделать заключение о состоянии удинской системы магматического питания.

По данным региональной сети сейсмических станций удинская активизация охватывает территорию $\sim 20 \times 20$ км и диапазон глубин до $\sim 20$ км. Привлечение данных временных сейсмических станций позволяет компактизировать область сейсмической активизации и обосновать связь регистрируемых сейсмических событий с конкретным вулканическим объектом. По данным временной сети показано, что (по крайней мере в мае-июле 2018 г.) землетрясения концентрировались под вулканом Большая Удина, а среда под Малой Удиной оставалось практически асейсмичной. Преобладающий диапазон глубин - 5-15 км. Облако эпицентров вытянуто в направлении север-северо-восток. Это простирание соответствует разлому (рис. 1в), пересекающему Большую Удину, и зоне основного глубинного магмопроводящего разлома в южной части КГВ (рис. 1а). 
История формирования УВК свидетельствует о всплесковом, пульсирующем развитии вулканизма этого района, проявившемся в чередовании эксплозивно-эффузивной деятельности с эпизодами покоя. Возможно, такой режим активности был связан с периодически возобновляемой связью корового очага и мантийного источника. Эта связь косвенно подтверждается синхронным излиянием на обоих Удинских вулканах лав основного состава. Поэтому наблюдаемая сейсмическая активизация может свидетельствовать об очередном эпизоде воздействия базальтового мантийного резервуара на коровый.

Важным аргументом, свидетельствующим об оживлении магматической системы Удинских вулканов, являются длиннопериодные (LP) землетрясения, объединяющиеся в «семейства» по схожести волновых форм. LP землетрясения связываются резонансными явлениями в магмопроводящих каналах при продвижении вязкой магмы. Эти процессы могут инициироваться поступлением новых порций вещества в питающую систему вулкана. Следовательно, УВК проявляет признаки движения вязкой магмы на глубинах средней коры, что является косвенным подтверждение возобновления связи между промежуточным очагом и мантийным источником после длительного периода покоя.

В 2017-2019 гг. сейсмическая активизация развивалась пульсирующе, с усилением. Учитывая, что землетрясения связаны с продвижением магмы в коровом очаге, можно предположить, что всплески сейсмичности связаны с эпизодами вброса мантийной магмы в промежуточный резервуар. То есть пульсирующий режим процессов в удинской магматической системе проявляется и на малых интервалах времени.

По геологическим данным о составе удинских пород, относящихся к базальтандезидацитовой формации, предполагается, что они могли сформироваться в коровом магматическом очаге и имеют признаки значительной магматической дифференциации; глубина этого очага оценивается в 10-20 км [Ермаков, 1977]. По инструментальным данным удинский очаг впервые проявился при построении сейсмотомографической модели КГВ [Кулаков и др., 2017]. В этой работе по материалам сейсмотомографического эксперимента 2014-2015 гг. под Удинскими вулканами была выявлена аномалия с пониженными значениями скоростей S-волн, которая рассматривается как область возможного скопления магмы. Аномалия имеет субвертикальный корень, а на юге она сливается с обширной аномальной зоной под ТЭЗ. Наиболее ярко аномалия проявилась в диапазоне глубин 8-15 км, что не противоречит опубликованным ранее оценкам глубины удинского корового очага. Отметим, что в 2014-2015 гг. сейсмическая активность под Удинскими вулканами отсутствовала, регистрировались лишь единичные фоновые 
события, а для сейсмотоморафии использовались землетрясения, происходившие в указанное время на всей территории КГВ.

Дополнительная, локальная сейсмотомографическая модель под УВК была построена по материалам временной сети 2018 г. Более подробно результаты этого эксперимента и методические вопросы томографических реконструкций по ограниченному числу сейсмостанций изложены в [Koulakov et al., 2019]. Для расчетов брались данные о временах вступлений P- и S-волн от землетрясений удинской активизации. Учитывая, что глубина этих событий в основном не превышает 20 км, просвечивался только приповерхностный коровый слой. Выявлена аномалия скоростей сейсмических волн (повышенная $\mathrm{V}_{\mathrm{P}}$, пониженная $\mathrm{V}_{\mathrm{S}}$, повышенное отношение $\mathrm{V}_{\mathrm{P}} / \mathrm{V}_{\mathrm{S}}$ ), расположенная под вулканом Большая Удина. Сопоставление сейсмотомографических реконструкций 2014-2015 гг. и 2018 г. представлено на рис.11 в сравнении с распределением по глубине удинских землетрясений, зарегистрированных временной сетью в мае-июле 2018 г. Видно, что аномалия, в 2014-2015 гг. наблюдавшаяся в диапазоне глубин 5-15 км, к 2018 г. сместилась в диапазон глубин до 5 км. Серия синтетических тестов, проведенная для оценки достоверности результатов сейсмической томогафии [Koulakov et al., 2019], позволяет утверждать, что модель обладает высоким разрешением и реалистично отражает реальное положение аномалии 2018 г. даже при использовании только четырех регистрирующих станций.

Максимум в распределении землетрясений по глубине соответствует экстремуму аномалии, выявленной по материалам 2014-2015 гг. и глубине удинского очага по [Ермаков, 1977]. Менее заглубленная аномалия 2018 г. землетрясениями не сопровождается. Данные сейсмотомографии могут свидетельствовать о распространении аномалии в область малых глубин под вулканом Большая Удина. Параметры аномалии позволяют предположить, что она связана с присутствием под УВК некоторого количества расплава и флюидов. Однако пока нет аргументов, которые свидетельствовали бы о проникновении магмы в постройку вулкана.

В 2017-2019гг. конфигурация зоны, охваченной активизацией, менялась. Визуально выделяются два кластера сейсмичности. Первый сформировался вдоль разлома, на котором расположены вулканы Большая и Малая Удина (простирание: запад-северозапад). Второй захватил северную, прилежащую к УВК, часть Толудской эпицентральной зоны. Миграция сейсмичности может быть связана с ветвлением системы даек, развивающейся в районе УВК.

Для сильнейшего землетрясения Удинской сейсмической активизации (06.02.2019 г., $\left.\mathrm{ML}=4.3, \mathrm{M}_{\mathrm{W}}=4.1\right)$ рассчитан механизм очага. Характер подвижки в очаге и 
направление оси превалирующего напряжения растяжения соответствует механизму очагов толудских землетрясений 2012 г., сопровождавших начало Трещинного Толбачинского извержения [Кугаенко и др., 2017а]. И удинское, и толудские землетрясения возникли под действием напряжения растяжения, ориентированного субширотно, что соответствует сейсмической проработке разлома растяжения: азимут оси Т напряжения растяжения составляет $\mathrm{Az}=277 \pm 6^{\circ}$ (погрешность соответствует среднеквадратичному отклонению). Толудские землетрясения рассматривались как результат внедрения и перемещения магмы вдоль разломной зоны. Аналогичную интерпретацию можно применить и к Удинскому землетрясению 06.02.2019 г.

В настоящее время вопрос о расположении глубинной области питания Удинских вулканов остается открытым. В работах [Koulakov et al., 2017; Кулаков и др., 2017 в юговосточной части КГВ выделено предположительно три источника питания извержений. Первый - транскоровая магмопроводящая колонна в центральной части Толбачинского Дола, выявленная по результатам сейсмической томографии и низкочастотного микросейсмического зондирования [Кугаенко и др., 2018]. Второй источник локализован под Толудской эпицентральной зоной, к югу от УВК. Третий подходит к вулкану Плоский Толбачик с севера, наклонно поднимаясь от области «корней» Ключевского вулкана. По сейсмическим данным удинский сейсмогенный объем 2017-2019 г., ассоциируемый с областью внедрения новой магмы, на юге сливается с ТЭЗ, на северо-западе - с облаком землетрясений вулкана Плоский Толбачик (рис. 3). Так что пространственно область питания Удинских вулканов может быть связана как с гипотетическим магматическим источником под ТЭЗ (как это предполагается в [Koulakov et al., 2019]), так и с зоной питания вулкана Плоский Толбачик. Не исключено и существование альтернативных, пока еще ненайденных путей поступления магмы под УВК. Для прояснения этих вопросов нужны дополнительные исследования.

\section{ЗАКЛЮЧЕНИЕ}

В течение полутора лет (октябрь 2017 г. - март 2019 г.) ведется мониторинг удинской сейсмической активизации - медленно усиливающегося потока длиннопериодных землетрясений под слабоизученным вулканическим комплексом в юговосточной части Ключевской группы вулканов. На момент написания статьи сейсмическая активизация продолжается. В данной работе сделана попытка связать сейсмические данные с процессами, развивающимися в недрах под вулканом, и проинтерпретировать их в комплексе с имеющейся геолого-геофизической информацией.

Сейсмическая активизация свидетельствует об оживлении магматической питающей системы под Удинским вулканическим комплексом. Под действием 
субширотного растяжения магма внедряется под вулкан Большая Удина. На глубине 515 км происходит продвижение вязкой магмы, сопровождаемое длиннопериодными (LP) землетрясениями, но, возможно, магма уже проникла и на меньшие глубины. Значительные изменения положения облака землетрясений могут быть связаны с разрастание объема среды, в который проникает магма.

Оживившийся (по сейсмическим данным) разлом С-СВ простирания, пересекающий Большую Удину, - часть системы основных глубинных разломов Ключевской группы вулканов. В частности трещинные извержения Толбачинского Дола группируются вдоль разрывов этого направления. Это же простирание имеет основной магмопроводящий разлом. Следовательно, Удинская активизация - эпизод (часть) единого для Ключевской группы магматического процесса.

Характерной особенностью магматической системы Удинского вулканического комплекса является пульсирующий характер развития вулканизма на временных масштабах в первые единицы тыс. лет. Эта особенность проявляется и на значительно более коротких интервалах времени, о чем свидетельствует динамика сейсмического процесса в ходе сейсмической активизации. Сейсмический процесс развивается нелинейно, имеет пульсирующий характер. Это свидетельствует о нестационарном, характере процессов, происходящих под вулканом (об импульсном характере поступления новых порций магмы в промежуточный очаг).

Сейсмические данные в комплексе с имеющейся геолого-геофизической информацией показывают, что Удинская магматическая питающая система проявляет признаки движения вязкой магмы на глубинах средней коры, что является косвенным подтверждение возобновления связи между промежуточным очагом и мантийным источником после длительного периода покоя. По нашему мнению, учитывая выводы, изложенные в исследованиях [Тимербаева, 1967; Ермаков, 1977], и сейсмическую активизацию 2017-2019 гг, УВК следует рассматривать как спящую или просыпающуюся группу вулканов.

Работа выполнена в рамках Госзадания ФИЦ ЕГС РАН (проект № 0152-2018-006) и научных проектов РФФИ № 18-55-52003 МНТ-а и № 19-05-00204-а.

\section{СПИСОК ЛИТЕРАТУРЫ}

Балеста С.Т. Земная кора и магматические очаги областей современного вулканизма. М., Наука, 1981, 134 с.

Богоявленская Г.Е., Брайцева О.А., Мелекесцев И.В., Максимов А.П., Иванов Б.В. Вулкан Безымянный // Действующие вулканы Камчатки. Т. 1. М., Наука, 1991, с. 168194. 
Большое трещинное Толбачинское извержение (1975-1976 гг., Камчатка) / Отв. ред. С.А. Федотов. М., Наука, 1984, 637 с.

Введенская А.В. Исследование напряжений и разрывов в очагах землетрясений при помощи теории дислокаций. М., Наука, 1969, 130 с.

Горшков Г.С., Богоявленская Г.Е. Вулкан Безымянный и особенности его последнего извержения 1955-1963 гг. М., Наука, 1965, 71 с.

Гусев А.А., Мельникова В.Н. Связи между магнитудами - среднемировые и для Камчатки // Вулканология и сейсмология, 1990, № 6, с. 55-63.

Дрознин Д.В., Дрознина С.Я. Интерактивная программа обработки сейсмических сигналов DIMAS // Сейсмические приборы, 2010, т. 46 (3), с. 22-34.

Дрознин Д.В., Дрознина С.Я., Сенюков С.Л., Чебров Д.В., Шапиро Н.М., Шебалин П.Н. Вероятностные оценки гипоцентров по данным камчатской сети сейсмических станций // Физика Земли, 2019, №4, с. 153-165.

Ермаков В.А. Формационное расчленение четвертичных вулканических пород. М., Недра, 1977, 223 с.

Кугаенко Ю.А., Павлов В.М., Иванова Е.И., Абубакиров И.Р., Салтыков В.А. Толудская вспышка сейсмичности и землетрясение 30.11.2012 г. $\left(\mathrm{M}_{\mathrm{C}}=5.4, \mathrm{M}_{\mathrm{W}}=4.8\right)$, сопровождавшие начало Толбачинского извержения 2012-2013 гг. // Вулканология и сейсмология, 2017a, № 6, с. 33-48.

Кугаенко Ю.А., Салтыков В.А., Абкадыров И.Ф., Воропаев П.В. Временные сейсмологические наблюдения в районе трещинного Толбачинского извержения 20122013 гг. и их результаты // Вулканология и сейсмология, 2017б, № 4, с. 67-82.

Кугаенко Ю.А., Салтыков В.А., Горбатиков А.В., Степанова М.Ю. Особенности глубинного строения зоны трещинных Толбачинских извержений (Камчатка, Ключевская группа вулканов) по комплексу геолого-геофизических данных // Физика Земли, 2018, № 3, c. $60-83$.

Кулаков И.Ю., Гордеев Е.И., Добрецов Н.Л., Сенюков С.Л., Кугаенко Ю.А., Абкадыров И.Ф., Яковлев А.В., Новгородова А.М., Кукарина Е.В.

Сейсмотомографические реконструкции земной коры и канала магматического питания // Толбачинское трещинное извержение 2012-2013 гг. (ТТИ-50) / Отв. ред. Е.И. Гордеев, Н.Л. Добрецов. Новосибирск, из-во СО РАН, 2017, с. 293-314.

Ландер А.В. Комплекс программ определения механизмов очагов землетрясений и их графического представления // Отчет Камчатской опытно-методической сейсмологической партии Геофизической службы РАН «Комплексные сейсмологические и геофизические исследования Камчатки и Командорских островов в 2003 г.». Фонды КФ ФИЦ ЕГС РАН. С. 359-380.

Мелекесцев И.В., Брайцева О.А., Пономарева В.В. Новый подход к определению понятия "действующий вулкан" // Геодинамика и вулканизм Курило-Камчатской островодужной системы. Петропавловск -Камчатский, ИВГиГ ДВО РАН, 2001, с.191-203.

Мелекесцев И.В., Хренов А.П., Кожемяка Н.Н. Тектоническое положение и общий очерк вулканов Северной группы и Среднного хребта // Действующие вулканы Камчатки. Т. 1. М., Наука, 1991. С. 74-78.

Новейший и современный вулканизм на территории России / / Отв. ред. Н.П. Лаверов, О.А. Богатиков, Н.Л. Добрецов. М., Наука, 2005, 604 с. 
Павлов В.М., Абубакиров И.Р. Алгоритм расчета тензора сейсмического момента сильных землетрясений по региональным широкополосным сейсмограммам объемных волн // Вестник КРАУНЦ. Науки о Земле. 2012, № 2 (20), с. 149-158.

Павлов В.М., Абубакиров И.Р. Расчет тензора сейсмического момента слабых камчатских землетрясений: первые результаты // Проблемы комплексного геофизического мониторинга Дальнего Востока России. Труды шестой научно-технической конференции. Петропавловск-Камчатский. 1-7 октября 2017 г. Обнинск, ФИЦ ЕГС РАН, 2017, с. 138142.

Салтыков В.А. Статистическая оценка уровня сейсмичности: методика и результаты применения на примере Камчатки // Вулканология и сейсмология, 2011, № 2, c. 53-59.

Салтыков В.А., Воропаев П.В., Кугаенко Ю.А., Чебров Д.В. Удинская сейсмическая активизация 2017-2018 гг. // Вестник КРАУНЦ. Науки о Земле. 2018, № 1 (37), c. 5-7.

Тимербаева К.М. Петрология Ключевских вулканов на Камчатке. М., Наука, 1967, 208 c.

Токарев П.И. Вулканические землетрясения Камчатки. М., Наука, 1981, 164 с.

Толбачинское трещинное извержение 2012-2013 г. (ТТИ-50) / Отв. ред. Е.И. Гордеев, Н.Л. Добрецов. Новосибирск, Из-во СО РАН, 2017, 421 с.

Федотов С.А. Энергетическая классификация Курило-Камчатских землетрясений и проблема магнитуд. М., Наука, 1972, 117 с.

Федотов С.А., Балеста С.Т., Двигало В.Н., Разина А.А., Флеров Г.Б., Чирков А.М. Новые Толбачинские вулканы // Действующие вулканы Камчатки. Т. 2. М., Наука, 1991, с. 214-274.

Чебров В.Н., Дрознин Д.В., Дрознина С.Я., Захарченко Н.З., Кугаенко Ю.А., Мельников Д.В., Мишаткин В.Н., Муравьев Я.Д., Нуждина И.Н., Рыбин А.В., Сенюков С.Л., Сергеев В.А., Сероветников С.С., Титков Н.Н., Фирстов П.П., Ящук B.B. Развитие системы комплексного инструментального мониторинга вулканов Дальневосточного региона // Сейсмические приборы, 2012, т. 48 (4), с. 40-54.

Чебров В.Н., Дрознин Д.В., Кугаенко Ю.А., Левина В.И., Сенюков С.Л., Сергеев В.А., Шевченко Ю.В., Ящук В.В. Система детальных сейсмологических наблюдений на Камчатке в 2011 г. // Вулканология и сейсмология, 2013, № 1, с. 18-40.

Чубарова О.С., Гусев А.А., Чебров В.Н. Свойства колебаний грунта при Олюторском землетрясении 20.04.2006 г. и его его афтершоках по данным цифровой регистрации // Вулканология и сейсмология, 2010, №2, с. 57-70.

Chouet B. Resonance of a Fluid-Driven Crack: Radiation Properties and Implications for the Source of Long-Period Events and Harmonic Tremor // J. Geophys. Res. Solid Earth. 1988, v. 93, p. 4375-4400.

Chouet B. A. Long-period volcano seismicity: its source and use in eruption forecasting // Nature, 1996, v. 380, p. 309-316.

Chouet, B.A., Page, R.A., Stephens, C.D., Lahr, J.C. \& Power, J.A. Precursory swarms of long-period events at Redoubt Volcano (1989-1990), Alaska: their origin and use as a forecasting tool // J. Volcanol. Geotherm. Res., 1994, v. 62 (1-4), 95-135.

Churikova T., Gordeychik B., Wörner G., Flerov G., Hartmann G., Simon K. Geochemical evolution of Bolshaya Udina, Malaya Udina, and Gorny Zub volcanoes, Klyuchevskaya Group (Kamchatka). Geophys. Res. Abstr, 2017, v. 19, EGU2017-10691. 
Diefenbach A., Guffanti M., Ewert J. Chronology and references of volcanic eruptions and selected unrest in the United States, 1980-2008. Open-File Report 2009-1118. U.S. Geological Survey, 2009, 85 p.

Espindola J. M., Zamora-Camacho A. and Z. Jiménez (2005) Earthquake families in the seismicity of Popocatépetl volcano // Geofís. J. Int., v. 44 (2), p. 169-176.

Frank W.B., Shapiro N.M., Gusev A.A. Progressive reactivation of the volcanic plumbing system beneath Tolbachik volcano (Kamchatka, Russia) revealed by long-period seismicity // Earth Planet. Sci. Lett., 2018, v. 493, p. 47-56.

Girina O.A. Chronology of Bezymianny volcano activity, 1956-2010 // J. Volcanol. Geotherm Res., 2013, v. 263, p. 22-41.

Koulakov I. LOTOS code for local earthquake tomographic inversion. Benchmarks for testing tomographic algorithms. BSSA, 2009, V. 99 (1), p. 194-214

Koulakov I., Gordeev E.I., Dobretsov N.L., Vernikovsky V.A., Senyukov S., Jakovlev A., Jaxybulatov K. Rapid changes in magma storage beneath the Klyuchevskoy group of volcanoes inferred from time-dependent seismic tomography // J. Volcanol. Geotherm Res., 2013, v. 263, p. 75-91.

Koulakov I., Abkadyrov I., Arifi N., Deev E., Droznina S., Gordeev E., Jakovlev A., Khrepy S., Kulakov R., Kugaenko Yu., Novgorodova A., Senyukov S., Shapiro N., Stupina T., West M. Three different types of plumbing systems beneath the neighboring active volcanoes of Tolbachik, Bezymianny and Klyuchevskoy in Kamchatka // J. Geophys. Res. Solid Earth, 2017, v. 122, is. 5, p. 3852-3874.

Koulakov I., Komzeleva V., Abkadyrov I., Kugaenko Yu, El Khrepy S. and Al Arifi N. (2019). Unrest of the Udina volcano in Kamchatka inferred from the analysis of seismicity and seismic tomography // J. Volcanol. Geotherm Res., 2019, v. 379, 45-59.

Kumagai H., Chouet B.A. The complex frequencies of long-period seismic events as probes of fluid composition beneath volcanoes // Geophys. J. Int., 1999, v. 138, 7-12.

Phillipson G., Sobradelo R., Gottsmann J. Global volcanic unrest in the 21st century: An analysis of the first decade // J. Volcanol. Geotherm Res., 2013, v. 264, p. 183-196.

Sgattoni G., Jeddi Z., Gudmundsson O., Einarsson P., Tryggvason A., Lund B., Lucchi F. Long-period seismic events with strikingly regular temporal patterns on Katla volcano's south flank (Iceland) // J. Volcanol. Geotherm Res., 2016, v. 324, p. 28-40.

Shapiro N.M., Droznin D.V., Droznina, S.Y., Senyukov S.L., Gusev, A.A., Gordeev E.I. Deep and shallow long-period volcanic seismicity linked by fluid-pressure transfer // Nat. Geosci., 2017, v. 10 (6), p. 442-445.

Volcanic Unrest: From Science to Society. Advances in Volcanology / Gottsmann J., Neuberg J., Scheu B. (Eds.) Springer Int. Publ., 2019, 298 p. 
Рис. 1. Ключевская группа вулканов.

а - схематическая карта вулканических образований по [Большое..., 1984; Мелекесцев и др., 1991; Федотов и др., 1991; Толбачинское..., 2017]: 1 - крупные голоценовые стратовулканы; 2 - крупные позднеплейстоцен-голоценовые стратовулканы; 3 голоценовые шлаковые конусы и их лавовые потоки; 4 - позднеплейстоценовые шлаковые конусы и их лавовые потоки; 5 - голоценовые кальдеры обрушения; 6 - кальдера обрушения на вершине Плоского Толбачика (1975 г.); 7 - лавовые плато; 8 дочетвертичные породы складчатого фундамента; 9 - флювиогляциальные и вулканогенно-пролювиальные отложения, аккумулятивные равнины; 10 - эруптивные центры и лавовые потоки последних исторических извержений Толбачинского Дола: А 2012-2013 гг., Б - 1975 г., В - 1975-1976 гг.; 11 - глубинные магмопроводящие разломы. Номерами обозначены действующие (Д) и потухшие (П) вулканы: 1 - Ключевской (Д), 2 Камень (П), 3 - Безымянный (Д), 4 - Средний (П), 5 - Крестовский (П), 6 - Ушковский (Д), 7 - Острый Толбачик (П), 8 - Плоский Толбачик (Д), 9 - Овальная Зимина (П), 10 Острая Зимина (П), 11 - Горный Зуб; 12 - Большая Удина (П), 13 - Малая Удина (П), 14 Толбачинский Дол (поле ареального вулканизма) (Д); 15 - щитовой вулкан Николка (П); б - региональные сейсмические станции (1); вулканы базальт-андезибазальтовой (2) и базальт-андезидацитовой (3) формации [Ермаков, 1977], номера вулканов те же; штриховкой отмечена область удинской сейсмической активизации; прямоугольником очерчен участок, представленный на рис. 1в; в - Удинский вулканический комплекс по [Тимербаева, 1967]: стратовулканы Большая и Малая Удина и позднеплейстоценголоценовые экструзии (кружки); разломы предполагаемые (штриховой пунктир) и установленные (сплошная линия). Точечным пунктиром оконтурена область Удинских эруптивных центров.

Рис. 2. Вулканы Большая Удина (справа, высота абсолютная 2923 м, относительная - 1600 м) и Малая Удина (слева, высота абсолютная 1945 м, относительная - 900 м). Вид с северо-запада. Фото И.Ф. Абкадырова.

Рис. 3. Сейсмичность Ключевской группы вулканов в 2015-2019 гг. Представлены карты эпицентров землетрясений по полугодиям (на рис.Зи - январь-март 2019 г.). Буквами отмечены облака эпицентров, относящиеся к отдельным вулканам (комментарии в тексте). На рис.Зи отмечен эпицентр сильнейшего землетрясения Удинской активизации и приведен механизм его очага в двух вариантах в соответствии с табл. 
Рис. 4. Временной ход энергетических параметров с июля 2017 г. по март 2019 г. Точками отмечены значения энергетического класса $\mathrm{K}_{\mathrm{s}}$ для удинских землетрясений. Крупными темными точками выделены землетрясения с $\mathrm{K}_{s} \geq 6.0$ (ML $\geq 2.25$ ). На вставке более детально представлен начальный этап удинской активизации. $\Sigma \mathrm{E}$ - кумулятивная сейсмическая энергия. $\Sigma \mathrm{N}$ - кумулятивное число землетрясений.

Рис. 5. Вариации уровня сейсмичности Удинской сейсмической активизации в различных временных окнах и цветовая шкала уровня сейсмичности СОУС’09 по [Салтыков, 2011].

Рис. 6. Динамика сейсмического процесса в ходе Удинской сейсмической активизации (октябрь 2017 г. - март 2019 г.): $a$ - карты эпицентров; б - плотность числа землетрясений; в - плотность выделившейся сейсмической энергии. Карты б и в построены для землетрясений представительного энергетического диапазона $\left(\mathrm{K}_{\mathrm{s}} \geq 3.9\right.$ $M L \geq 1.2)$ и нормированы на локальные максимумы параметров. Звездой отмечен вулкан Большая Удина.

Рис. 7. Результаты расчета механизма землетрясения 6.02.2019 г. по широкополосным сейсмограммам. На панели $\boldsymbol{a}$ приведены зависимость невязки от пробной глубины, оптимальный механизм и положение сейсмостанций (ESO, KLY, KIR, KBG) относительно эпицентра. На панели б - волновые формы: наблюденные (1) и синтетические (2); указаны интервалы подгонки (3). Как наблюденные, так и синтетические волновые формы фильтровались в полосе периодов 16-25 с. Вертикальная компонента на станции Ключи (KLY) и горизонтальные компоненты на станции Эссо (ESO) при расчете ТСM не использовались из-за сильного шума.

Рис. 8. Длиннопериодные (LP) землетрясения удинской сейсмической активизации.

Примеры записей и спектры LP трех землетрясений (a), для сравнения приведены спектры фоновых сигналов за 1-2 мин. перед землетрясениями. Примеры повторяемости волновых форм и соответствующие «семейства» сейсмических событий (б, в).

Рис. 9. Распределения аномалий скоростей Р и S волн и отношение $\mathrm{Vp} / \mathrm{Vs}$, полученные в результате томографической инверсии данных по локальной сейсмической сети на горизонтальном сечении на глубине 3 км (верхний ряд) и двух вертикальных 
сечениях (второй и третий ряд), положение которых показано на картах. Треугольники на картах показывают положение станций. Изолинии рельефа проведены с интервалом 500 м. Точки показывают проекции землетрясений на сечения. Нижний ряд - результат восстановления синтетической модели, заданной вдоль профиля 1А-1В. Конфигурация синтетических аномалий показана линиями.

Рис. 10. Сейсмичность в районе Удинского вулканического комплекса в мае-июле 2018 г., во время работы временных станций. Эпицентры землетрясений по каталогу региональной сети (а), наборы данных N1 (б) и N2 (в) (описание в тексте). На рис. 10в черными точками для сравнения нанесены эпицентры землетрясений, соответствующих N2, по данным каталога региональной сети. Более детальное представление набора данных N1 с разложением по четырем диапазонам глубин (г). Штриховым пунктиром отмечен разлом север-северо-восточного простирания, пересекающий вулкан Большая Удина. Светлые треугольники - временные, темные - региональные сейсмические станции. Вулканы соответствуют рис. 1.

Рис. 11. Сопоставление глубинного распределения удинских землетрясений с глубиной скоростных аномалий, выделенных в разные годы под вулканом Большая Удина в работах [Кулаков и др., 2017; Koulakov et al., 2019]. Распределение по глубине гипоцентров землетрясений N1 и N2 (а) и экстремумы сейсмотомографических аномалий (б): максимальные относительные отклонения $\mathrm{V}_{\mathrm{P}}$ и $\mathrm{V}_{\mathrm{S}}$ от локальной скоростной модели и значения отношения $\mathrm{V}_{\mathrm{p}} / \mathrm{V}_{\mathrm{s}}$. 
Табл. Механизм очага землетрясения 06.02.2019 г. ML=4.3.

\begin{tabular}{|c|c|c|c|c|c|c|c|c|c|c|c|c|c|}
\hline \multirow{3}{*}{$\begin{array}{l}\text { Использованные } \\
\text { данные }\end{array}$} & \multicolumn{6}{|c|}{ Главные оси ${ }^{1}$} & \multicolumn{6}{|c|}{ Механизм очага ${ }^{2}$} & \multirow{3}{*}{ Диаграмма } \\
\hline & \multicolumn{2}{|c|}{$T$} & \multicolumn{2}{|c|}{$N$} & \multicolumn{2}{|r|}{$P$} & \multicolumn{3}{|c|}{$N P 1\left(^{\circ}\right)$} & \multicolumn{3}{|c|}{$N P 2\left(^{\circ}\right)$} & \\
\hline & $p l$ & azm & $p l$ & azm & pl & azm & stk & dip & slip & stk & dip & slip & \\
\hline $\begin{array}{l}\text { Знаки первых } \\
\text { вступлений } \\
\text { Р-волн }\end{array}$ & 7 & 113 & 37 & 18 & 52 & 213 & 354 & 62 & -132 & 238 & 50 & -38 & \\
\hline $\begin{array}{l}\text { Широкополосные } \\
\text { сейсмограммы }\end{array}$ & 17 & 277 & 73 & 32 & 16 & 185 & 322 & 74 & -174 & 230 & 84 & -16 & \\
\hline
\end{tabular}

\section{Примечание:}

1) Ориентация оси задается двумя углами - углом погружении $\mathrm{pl}$ и азимутом $\mathrm{azm}$

2) Ориентация нодальной плоскости задается двумя углами - азимутом простирания stk и углом падения dip. Угол подвижки slip - угол в плоскости очага между направлением простирания и вектором подвижки (отсчитывается от направления простирания против часовой стрелки).

3) Использована равноплощадная проекция нижней полусферы. P - ось сжатия, Т - ось растяжения. Заштрихована область волн сжатия. 


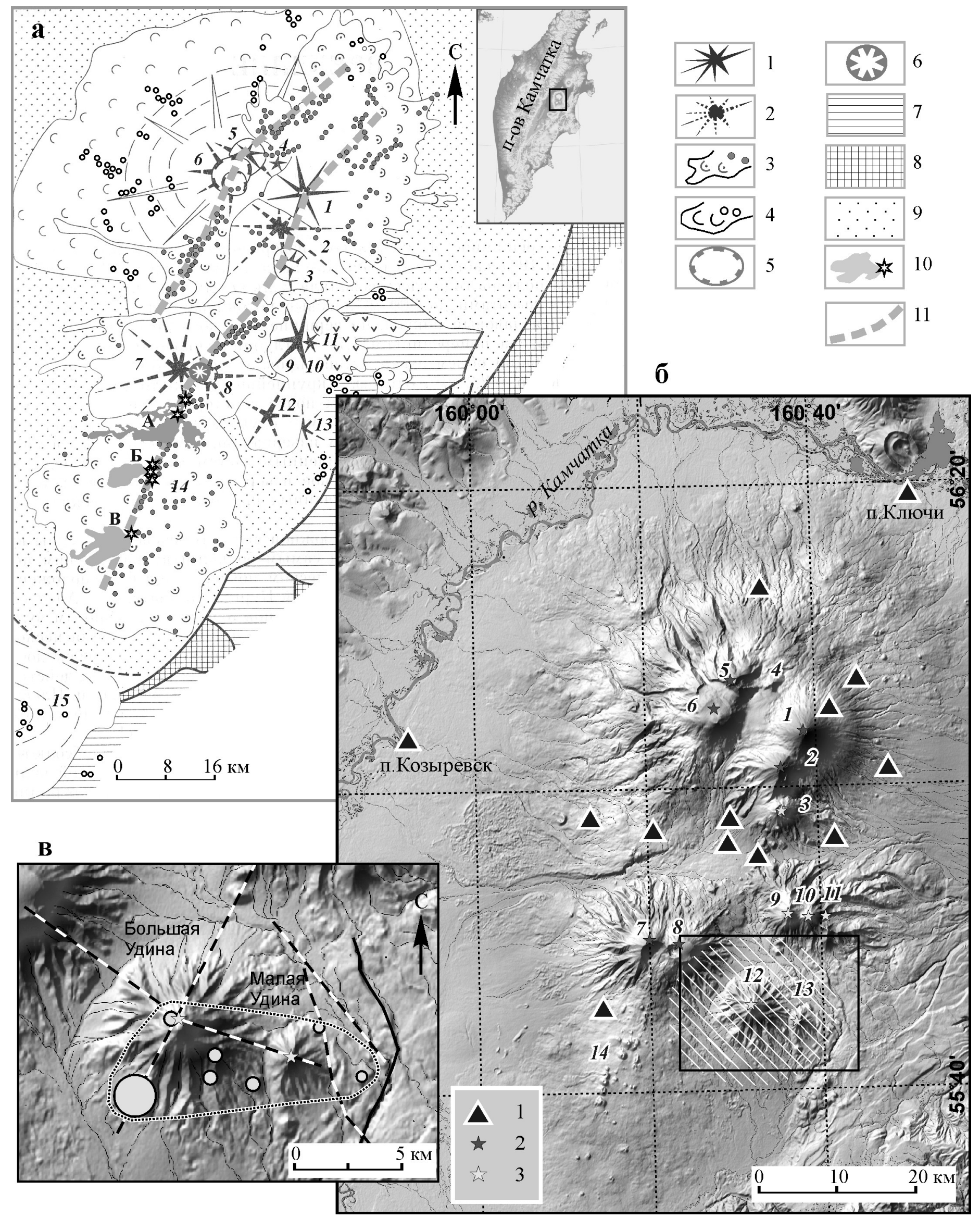




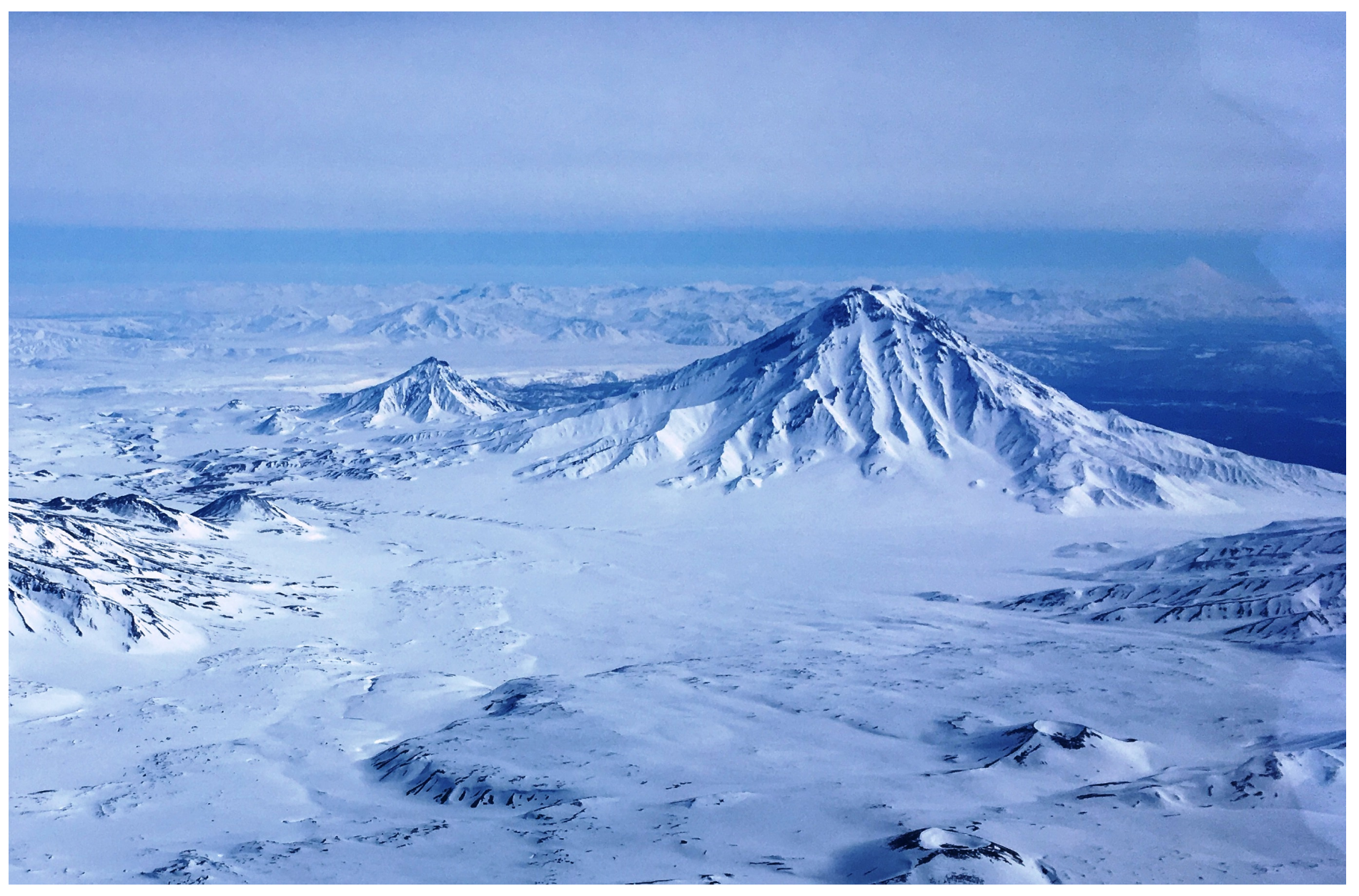



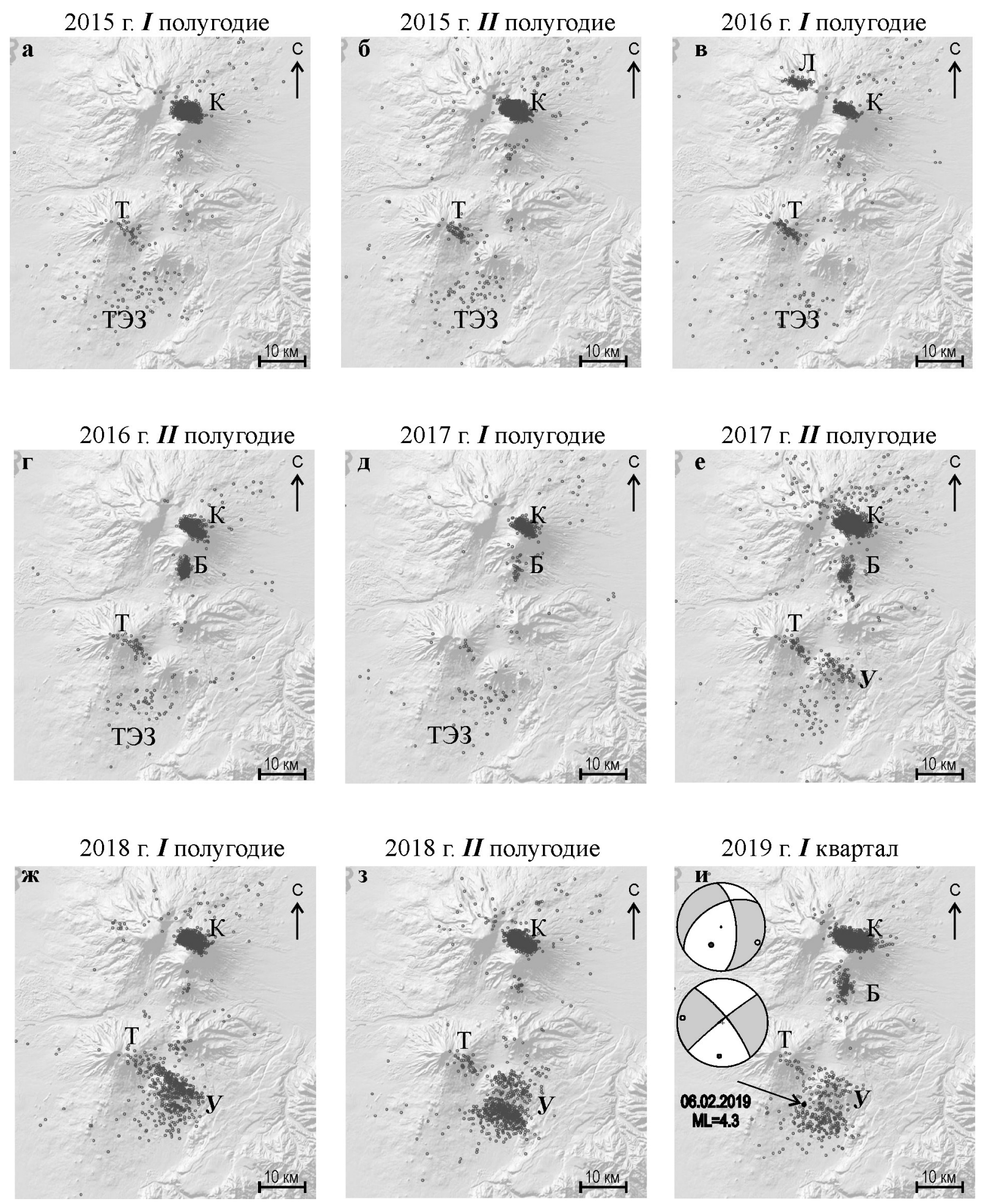


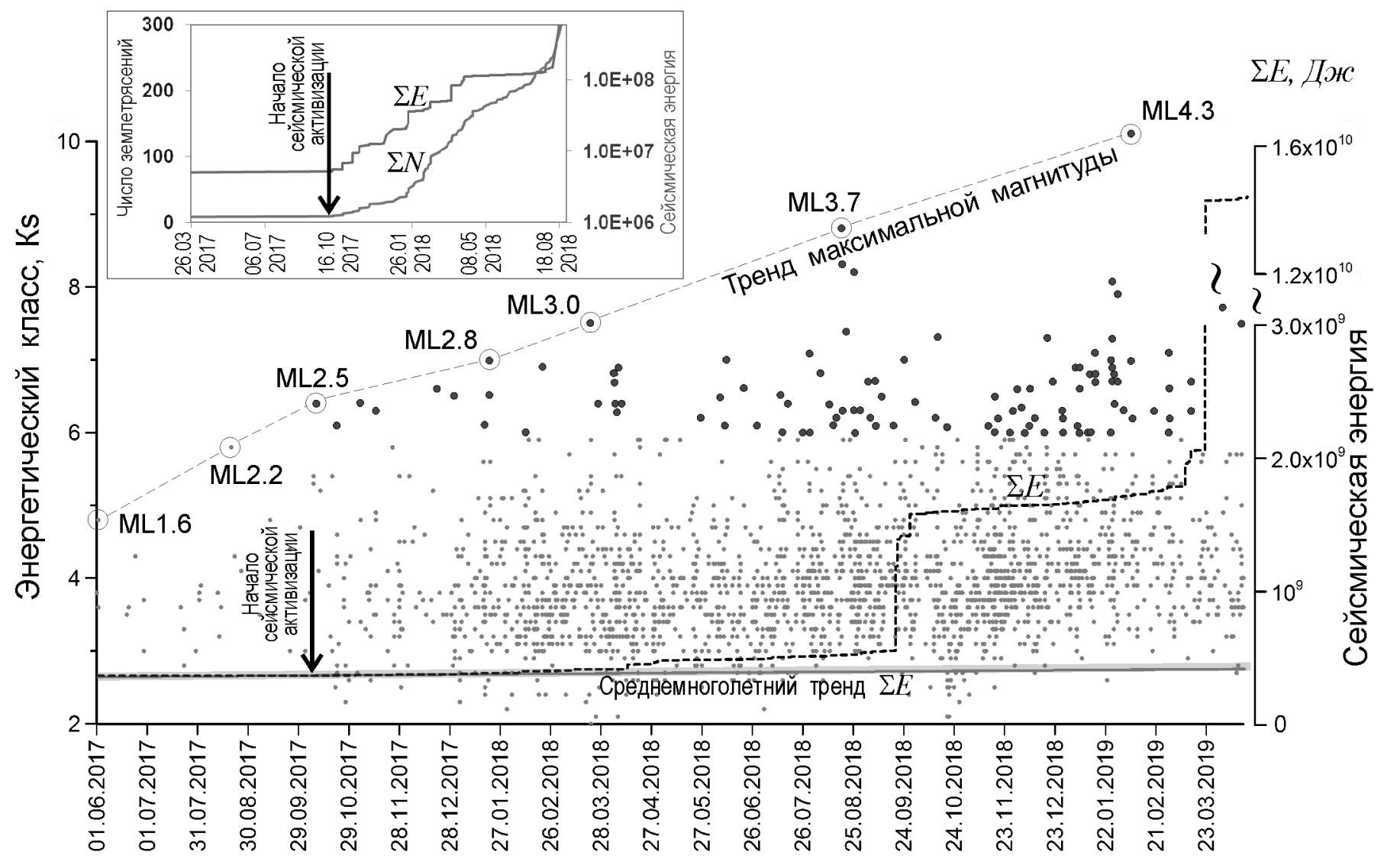


Уровень сейсмичности по шкале СОУС'09

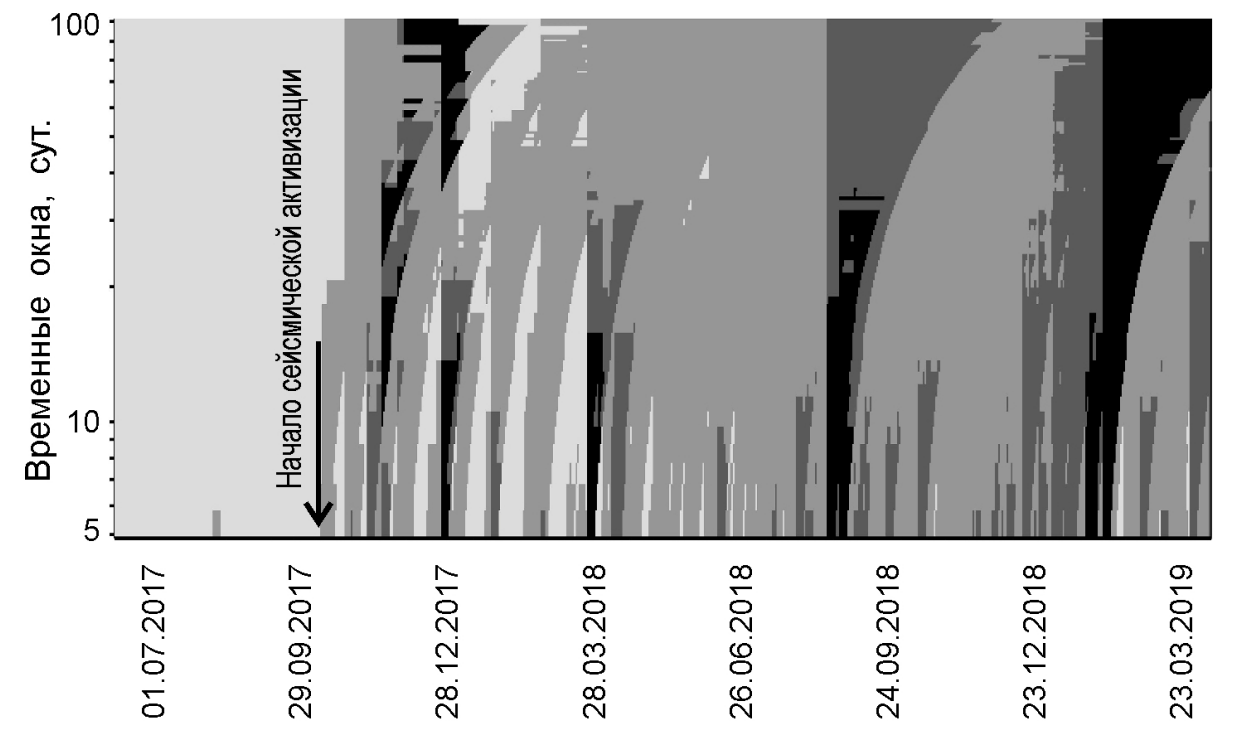

\section{Шкала СоУС'09}

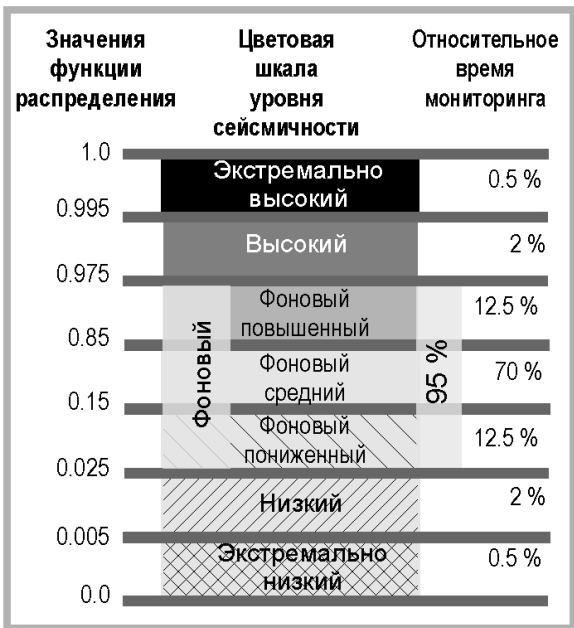




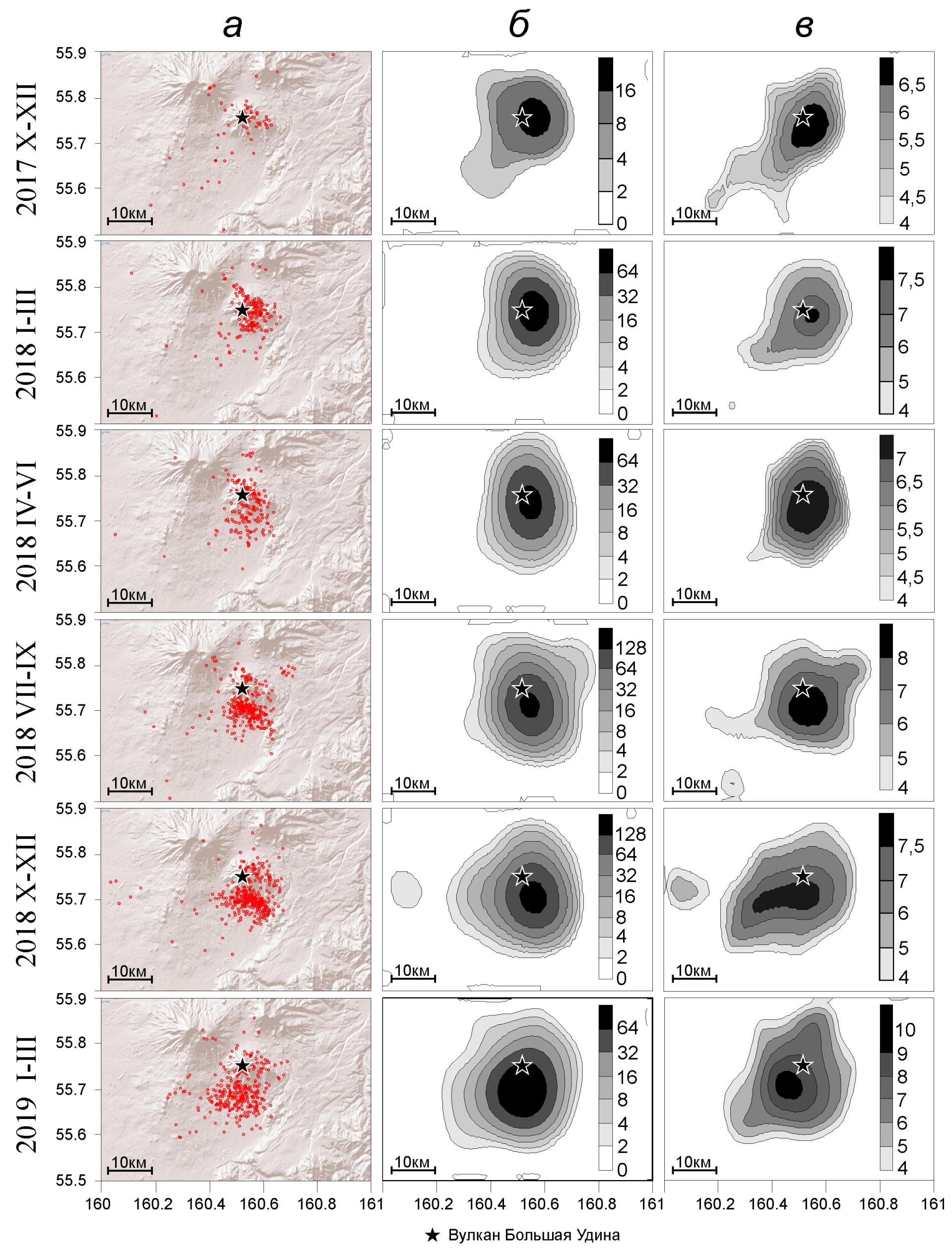




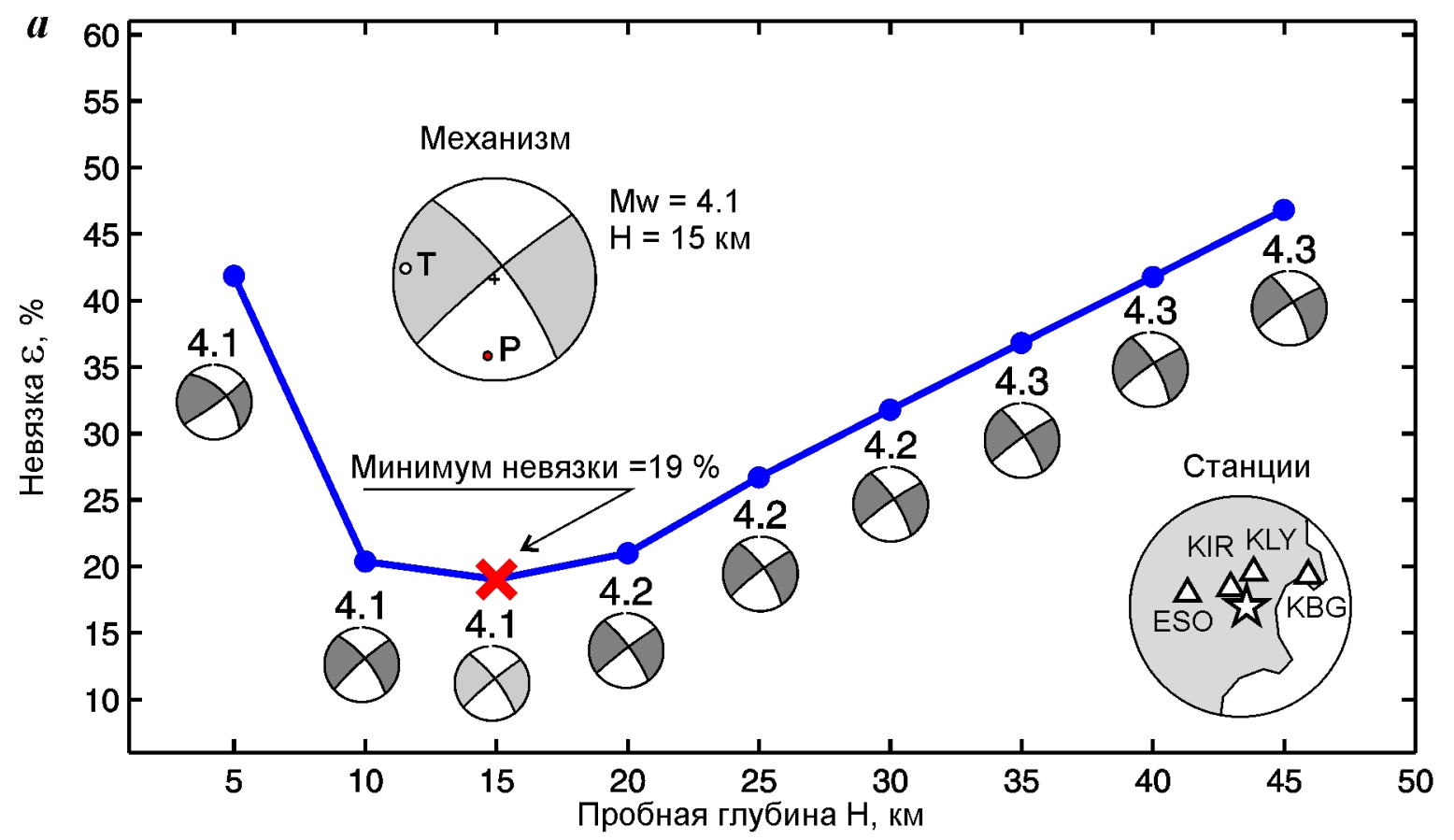

б

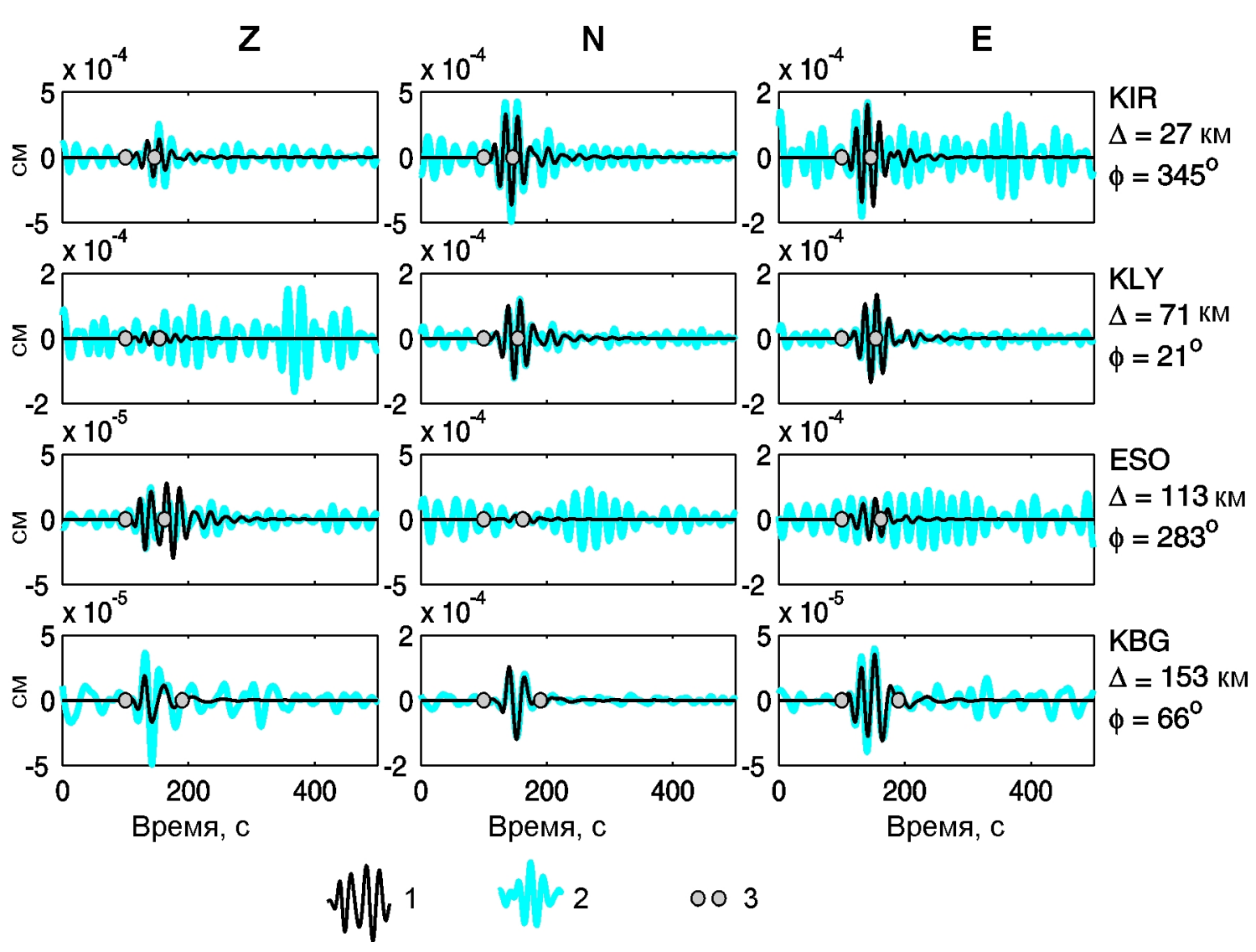



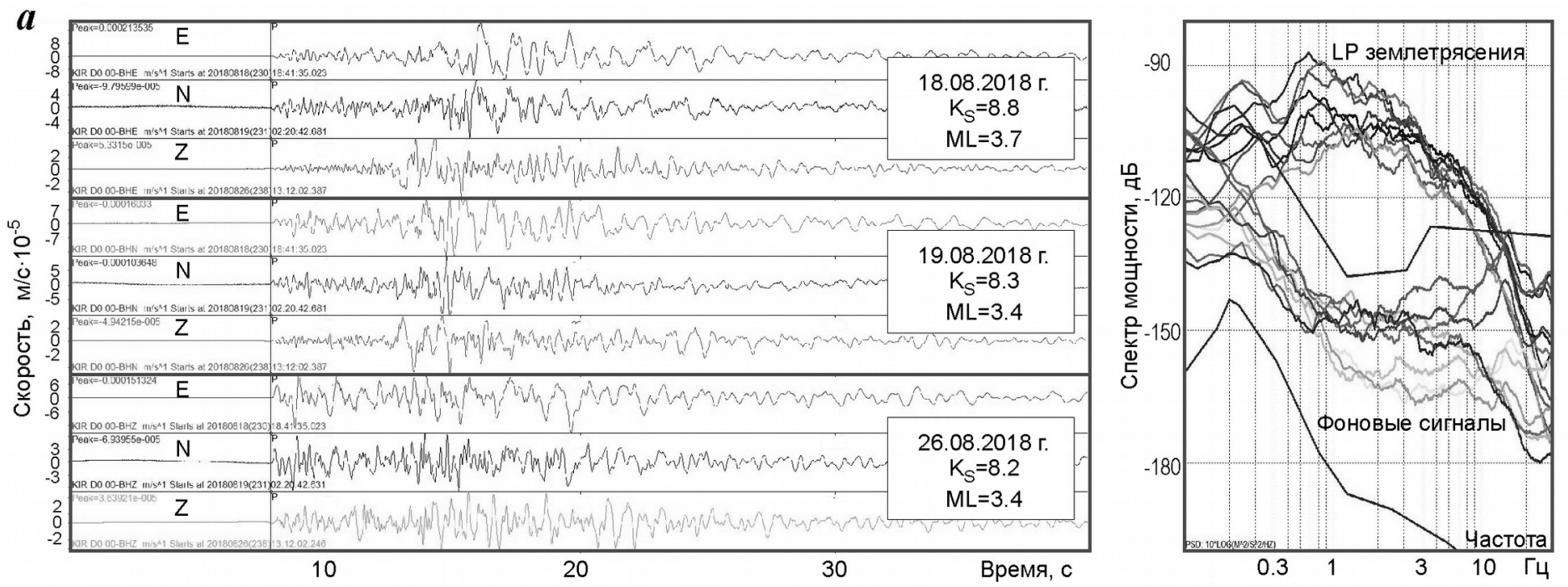

06.06.2018 г. Вертикальный канал. Временная станция Ud04.

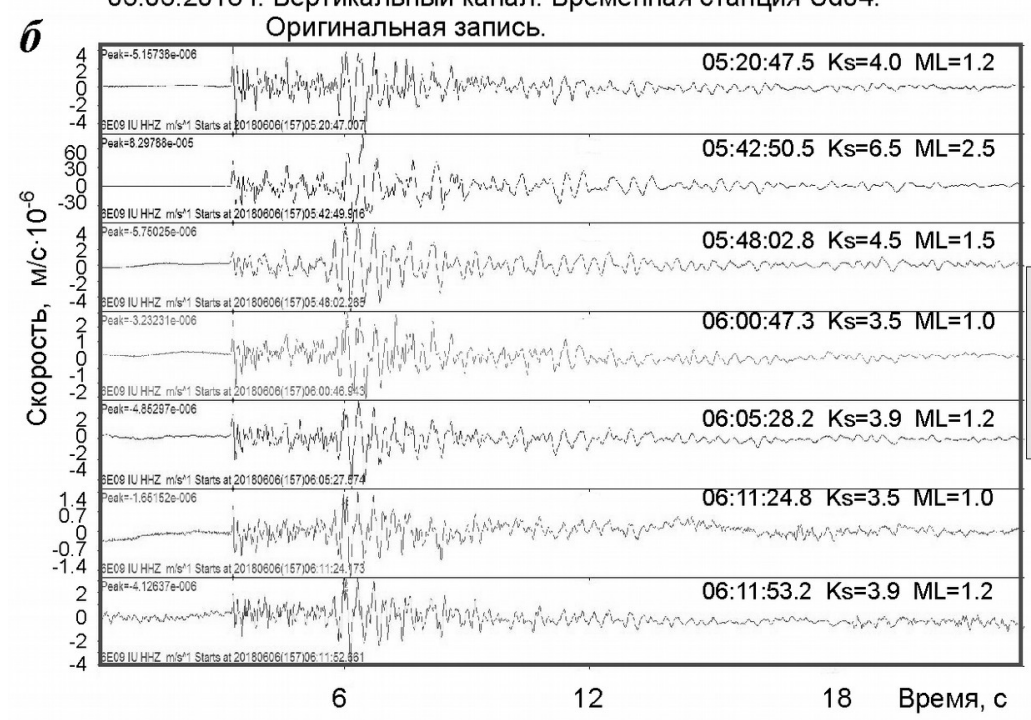

Наложение волновых форм. Фильтр 1-3 Гц.

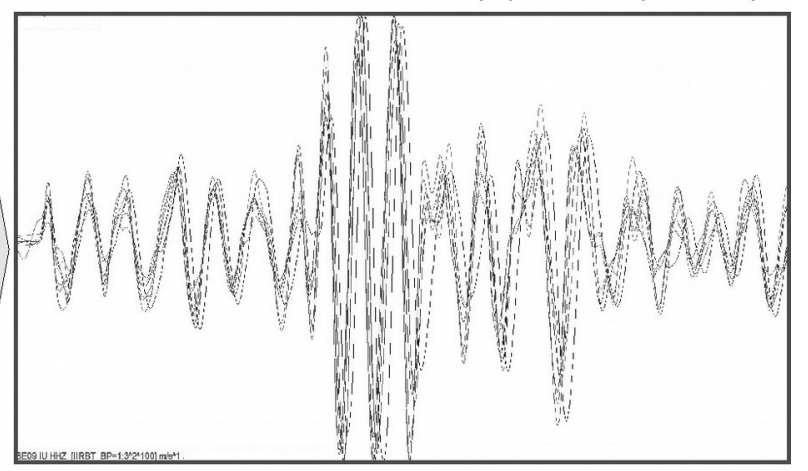

( 25.08.2018 г. Вертикальный канал. Региональная станция BZP.

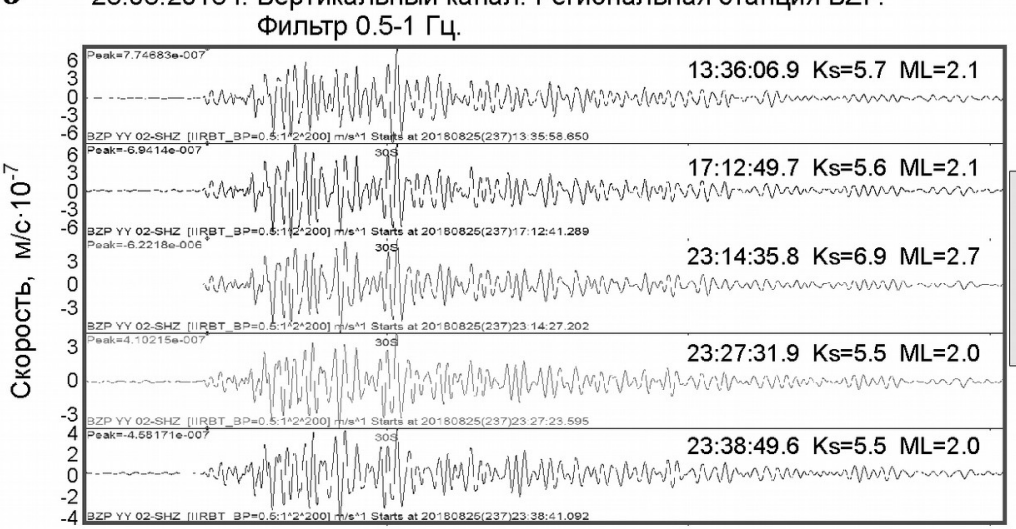

30

60

Время, с

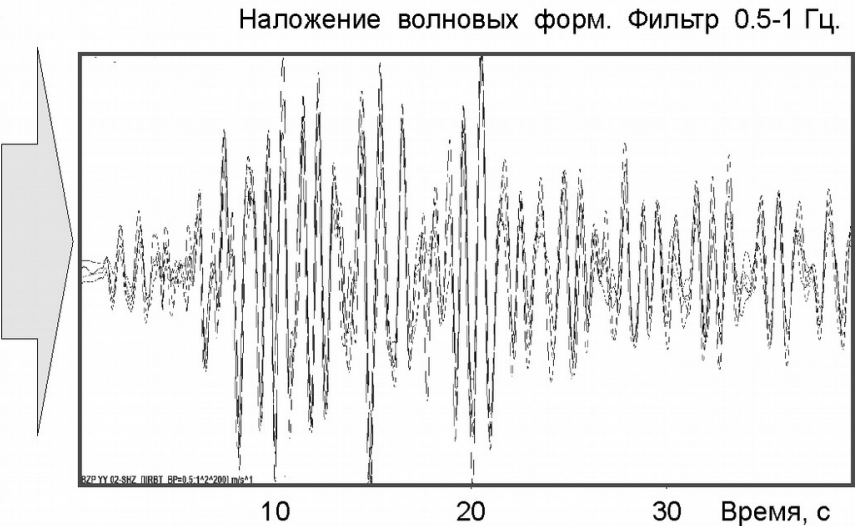



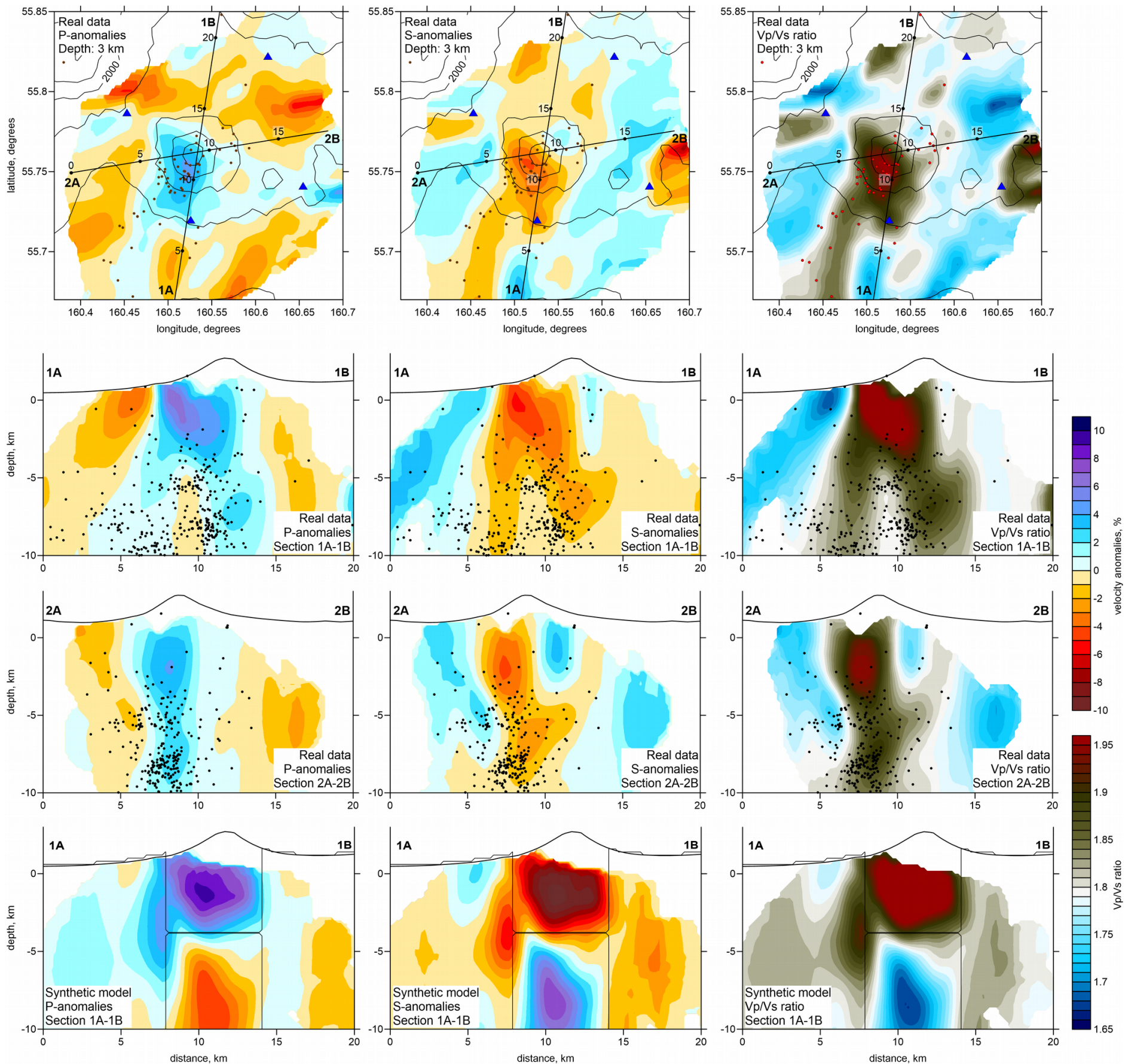
a

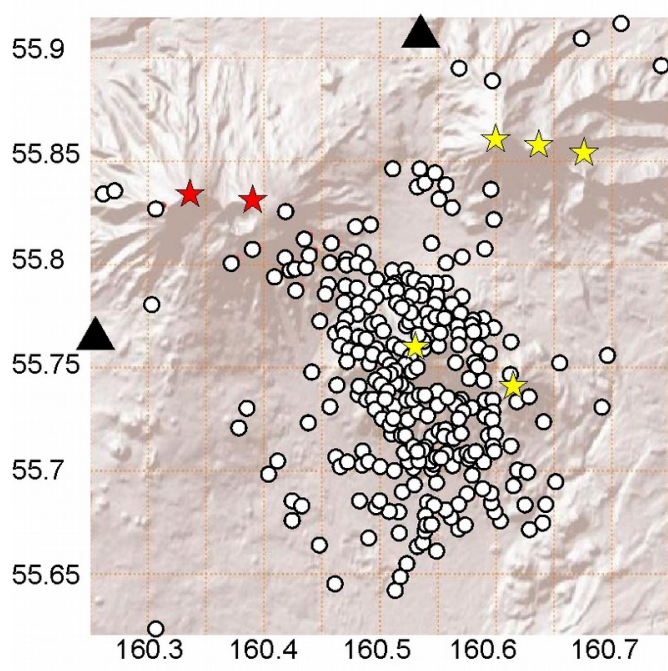

б

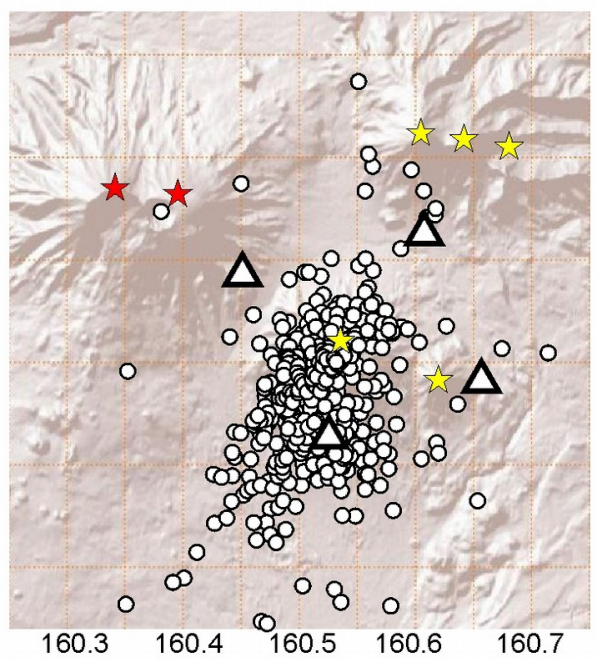

B

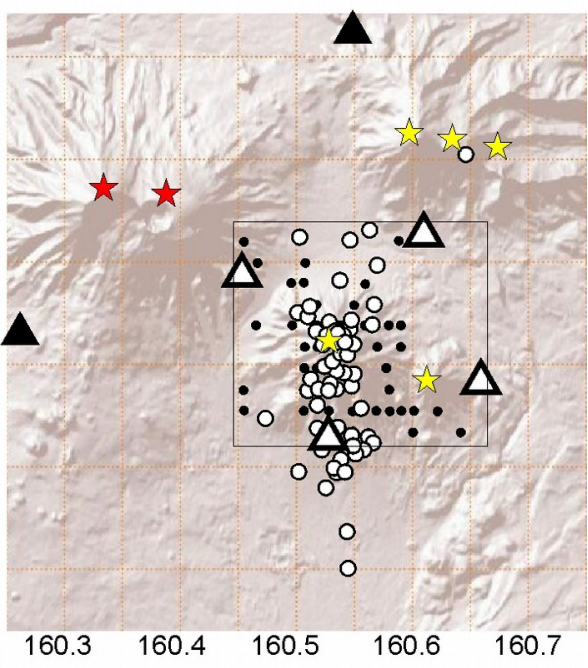

$\Gamma$
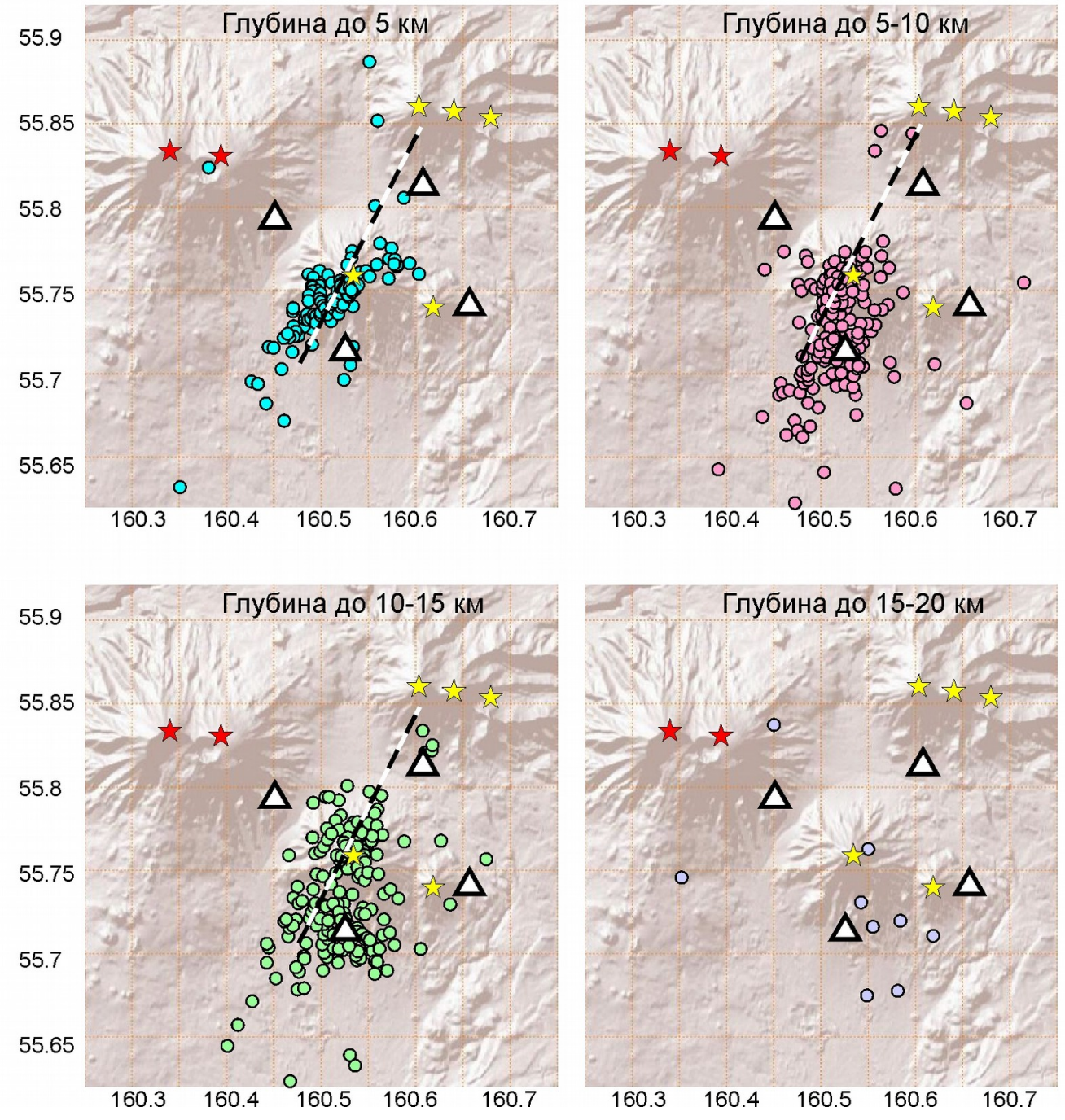
a

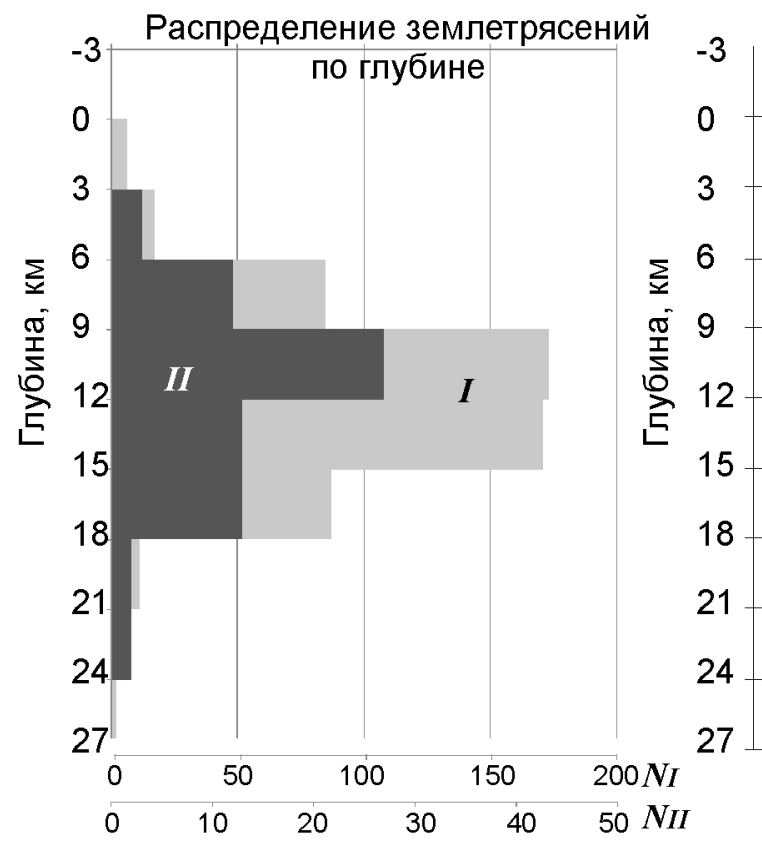

6

Аномалии сейсмических скоростей

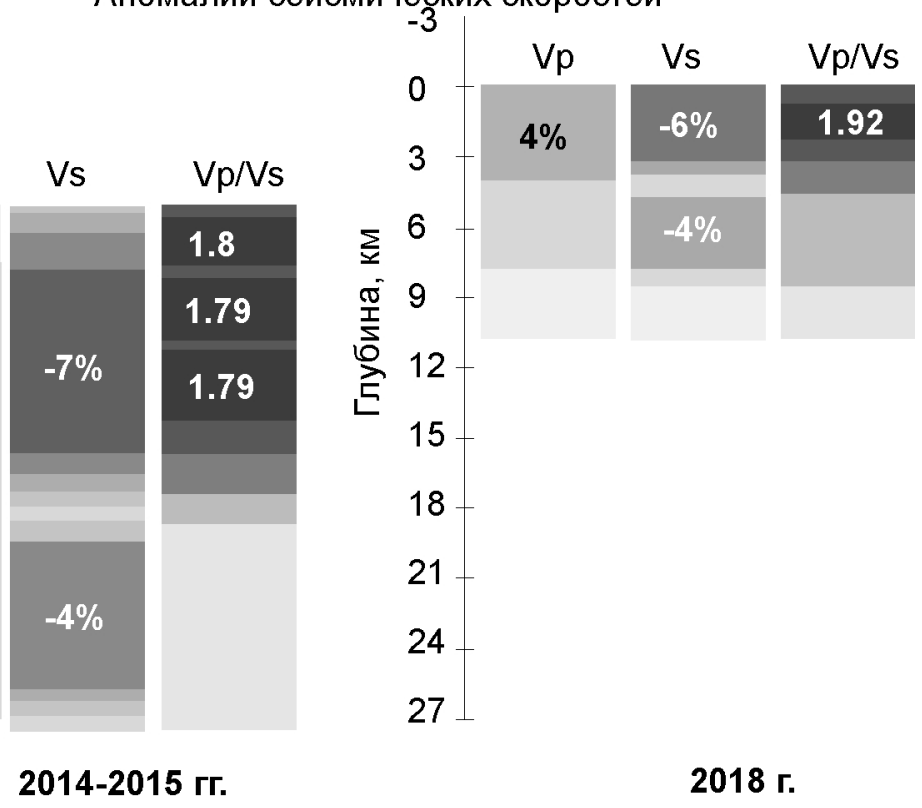

